\title{
Aborsi Akibat Pemerkosaan dan Kedaruratan Medis Menurut Hukum Islam*
}

\author{
(DUE ABORTION RAPE AND EMERGENCY MEDICAL \\ ACCORDING TO ISLAMIC LAW)
}

\author{
Munawaroh \\ Fakultas Syariah dan Hukum UIN Jakarta \\ Jl. Ir. H. Juanda No. 95 Ciputat Tangsel \\ E-mail: munawarah@yahoo.com
}

\begin{abstract}
Perform Abortion is basically prohibited under any law whatsoever, either in the positive law and in Islamic law. Because the act of abortion is a criminal offense with murder of candidate human lives in the womb. However, other conditions then gives leeway do this forbidden actions, such as in cases of rape and medical emergencies, which, if not performed abortions would result in danger to the life of the mother. Therefore, the debate will be this exception still occurs. So it is necessary to conduct in-depth research on the issue.
\end{abstract}

Keywords: Abortion, Rape, Medical Emergencies

\begin{abstract}
Abstrak: Melakukan Aborsi pada dasarnya dilarang dalam setiap aturan hukum apapun, baik dalam hukum positif maupun dalam hukum Islam. Karena perbuatan aborsi merupakan tindak pidana pembunuhan berencana terhadap nyawa calon manusia dalam kandungan. Akan tetapi kondisi lain kemudian memberikan kelonggaran melakukan perbuatan terlarang ini, seperti pada kasus pemerkosaan dan kedaruratan medis, yang apabila aborsi tidak dilakukan akan berakibat bahaya terhadap nyawa sang ibu. Oleh karenanya, perdebatan akan pengecualiannya masih terus terjadi. Sehingga dipandang perlu untuk melakukan penelitian mendalam terhadap permasalahan ini.
\end{abstract}

Kata Kunci: Aborsi, Pemerkosaan, Darurat Medis

* Diterima tanggal naskah diterima: 23 Juli 2015, direvisi: 24 Agustus 2015, disetujui untuk terbit: 27 Oktober 2015. 


\section{Pendahuluan}

Kesehatan perempuan sekarang sudah merupakan kepedulian dunia. Suatu perkembangan yang didasarkan kepada estimasi bahwa hanya $24 \%$ dari penduduk dunia mempunyai akses pada layanan aborsi aman dengan alasan yang secara sosial dibenarkan. 13\% karena alasan medis dan sebanyak $24 \%$ aborsi dibenarkan dengan alasan melindungi kehidupan si ibu. Ada negara yang sama sekali tidak membenarkannya, seperti di Amerika Latin, dokter swasta melakukannya dengan meminta imbalan yang sangat tinggi. Kesehatan perempuan menarik perhatian dunia karena kesehatan perempuan menentukan hari depan kita. Perempuan yang diposisikan sebagai perawat dan pendidik pertama dan utama dari generasi yang akan datang harus sehat fisik, mental, dan sosial. ${ }^{1}$

Dalam pandangan (Islam) hak reproduksi adalah hak yang diberikan Tuhan karena fungsi reproduksinya yang khas dan karenanya perlu dijamin hak-haknya. Aborsi adalah dilema khas perempuan karena hanya perempuan yang mempunyai sistem dan fungsi reproduksi yang memungkinkannya hamil, dan hanya perempuan yang mengalami kehamilan yang tidak dikehendaki. Latar belakang terjadinya kehamilan yang tidak direncanakan sangat beragam. Mulai dari ketidaktahuan perempuan perihal sistem reproduksinya sampai dengan kegagalan melindungi diri dari kehamilan yang tidak dikehendaki. Dilema aborsi dialami perempuan ketika perlu memilih dan memutuskan bagaimana menghidupi kehamilan yang tidak dikehendaki karena ia harus memutuskan sesuatu yang secara langsung merupakan bagian dari dirinya. Aborsi yang dialami perempuan bervariasi. Variasi pilihannya dipengaruhi oleh faktor kondisi pribadi dan keluarganya, nilai-nilai agama dan budaya. ${ }^{2}$

Menurut istilah kesehatan, aborsi di definisikan sebagai penghentian kehamilan setelah tertanamnya sel telur (ovum) yang telah dibuahi dalam rahim (uterus) sebelum usia janin mencapai dua puluh minggu. Sedangkan definisi aborsi yang lebih lengkap disampaikan oleh Abul Fadl Mohsin Ebrahim. Menurutnya aborsi ialah pengakhiran kehamilan baik secara sengaja maupun tidak sengaja, spontan akibat kelainan fisik wanita atau melalui

1 Maria Ulfa Anshor, Fikih Aborsi (Wacana Penguatan Hak Reproduksi Perempuan). (Jakarta: Buku Kompas, 2006), Cetakan pertama, h. 5

2 Maria Ulfah Anshor, Fikih aborsi (Wacana Penguatan Hak Reproduksi Perempuan), (Jakarta: Buku kompas, 2006), Cetakan pertama, h. 6 
campur tangan manusia, seperti meminum obat-obatan tertentu atau menggunakan jasa dukun untuk melakukan praktik aborsi. ${ }^{3}$

Di tinjau dari sudut pandang psikologi, ini berarti bahwa bisa menyediakan prosedur aborsi yang secara medis dan psikologis dapat dipertanggungjawabkan perempuan dalam menghadapinya.

Aborsi diatur dalam kitab Undang-undang hukum pidana (KUHP), pasal 346, pasal 347, pasal 348, pasal 349 adalah sebagai berikut:

- Pasal 346; "Seseorang yang sengaja menggugurkan kandungan atau mematikan kandungan atau menyuruh orang lain untuk itu, diancam dengan pidana paling lama empat tahun."

- Pasal 347; "Barang siapa dengan sengaja menggugurkan kandungan atau mematikan kandungan seorang wanita tanpa persetujuannya, diancam dengan pidana penjara paling lama dua belas tahun. Jika perbuatan itu mengakibatkan matinya wanita tersebut, diancam dengan pidana penjara paling lama lima belas tahun.

- Pasal 348: Barang siapa dengan sengaja menggugurkan atau mematikan kandungan seorang wanita dengan persetujuannya, diancam dengan pidana penjara paling lama lima tahun enam bulan. Jika perbuatan itu mengakibatkan matinya wanita tersebut, diancam dengan pidana penjara paling lama tujuh tahun.

- Pasal 349; "Jika seorang tabib, dukun beranak atau tukang obat membantu melakukan kejahatan berdasarkan pasal 346 ataupun melakukan atau membantu melakukan salah satu kejahatan yang diterangkan dalam pasal 347 dan 348, maka ada pidana yang ditentukan dalam pasal itu dapat ditambah dengan sepertiga dan ia dapat dipecat dari jabatan yang digunakan untuk melakukan kejahatan." 4

Pada intinya pasal-pasal tersebut menyatakan bahwa tuntutan dikenakan bagi orang yang melakukan tindakan aborsi ataupun orang-orang

${ }^{3}$ M Nurul Irfan, (Gratifikasi dan Kriminalitas Seksual Dalam Hukum Pidana Islam), (Jakarta: Amzah.2014), h. 91

${ }^{4}$ Maria Ulfa Anshor, Fikih Aborsi (Wacana Penguatan Hak Reproduksi Perempuan). (Jakarta: Buku Kompas, 2006), Cetakan pertama, h. 52-56 
yang membantu melakukan tindakan aborsi baik secara langsung maupun tidak langsung. ${ }^{5}$

Aborsi sama halnya dengan menggugurkan kandungan pada janin. Setelah ruh ditiupkan kalangan fukaha membedakan hukum aborsi saat ruh telah ditiupkan ke janin, sebelum ditiupkan, dan setelah janin menetap di dalam rahim.

Penting untuk disampaikan bahwa yang dibicarakan disini hanya hakhak umum yang diberikan hukum Islam kepada janin. Dan, istilah janin digunakan dalam pengertian yang lebih luas, yaitu sesuatu yang muncul dalam rahim ibu setelah pembuahan terjadi. Hak untuk hidup; hukum Islam menetapkan bahwa janin memiliki hak untuk hidup. Hal ini diperkuat dengan fakta bahwa semua mazhab memerintahkan untuk menunda pelaksanaan hukuman mati bagi seorang wanita hamil sampai setelah dia melahirkan. Kemudian mengenai warisan; hukum Islam mengatakan bahwa selama janin masih berada dalam rahim ibunya, dia tidak secara langsung memiliki hak waris. Karena itu, jika pemberi wasiat meninggal sedangkan janin belum lahir, maka pembagian warisan harus ditunda sampai janin lahir. Penguburan bayi; hukum Islam mengatakan bahwa janin yang gugur atau lahir mati harus dikebumikan. Ibn 'Abidin menunjukan bahwa janin yang tidak mengeluarkan suara pada saat lahir harus dimandikan (ghusl), diberi nama, dibungkus dalam selembar kain (kaffan) dan dikubur, tetapi tidak dibacakan do'a. ${ }^{6}$

Tentang hukum aborsi saat ruh telah ditiupkan ke janin, kalangan fukaha sepakat atas keharamannya. Ruh ditiupkan saat janin berumur 120 hari (empat bulan) sebagaimana disebutkan dalam hadits shahih yang diriwayatkan secara marfu' oleh Ibnu Mas'ud. Rosulullah SAW bersabda:

"Sesungguhnya salah seorang dari kalian berada dalam perut ibunya selama empat puluh hari berupa air mani, empat puluh hari berikutnya menjadi segumpal darah, lalu empat puluh hari berikutnya menjadi segumpal daging, kemudian malaikat diutus untuk meniupkan ruh kepadanya."(HR Muslim) ${ }^{7}$

\footnotetext{
${ }^{5}$ Dewi Indraswati, Fenomena Kawin Muda dan Aborsi: Gambaran Kasus dalam Hasyim, S, Menakar Harga Perempuan,(Jakarta: Sinar Grafika, 2001), h. 132

${ }^{6}$ Abul Fadl Mohsin Ebrahim, Aborsi Kontrasepsi dan Mengatasi Kemandulan (Isu-isu Biomedis Dalam Perspektif Islam. (Bandung : Penerbit Mizan Anggota IKAPI, 1997), h. 139

${ }^{7}$ Imam Muslim, Shahih Muslim. (Beirut: Dar El Fiker, 1993. Hadis 2643, jilid 2, h. 412). Lihat juga hadis 2645, h. 414.
} 
Tidak ada perbedaan pendapat di kalangan fukaha tentang hukum aborsi setelah ruh ditiupkan ke dalam janin. Mereka menandaskan, hukumnya sama seperti membunuh orang bernyawa. Hukum haram ini tetap berlaku meskipun tindakan membiarkan janin di dalam kandungan bisa membahayakan nyawa si ibu. Ibnu 'Abidin menegaskan, "seandainya janin itu hidup, dan keberadaannya dikhawatirkan bisa membahayakan nyawa si ibu, maka menggugurkan janin tetap dibolehkan. Demikian itu karena kematian si ibu termasuk sesuatu yang mungkin bisa terjadi dan mungkin tidak (mauhum). Oleh karena itu tidak dibolehkan membunuh orang karena sesuatu yang masih mauhum. Sedangkan Sebelum ruh ditiupkan ada perbedaan pendapat dikalangan mazhab fikih, bahkan dalam satu mazhab sekalipun, tentang hukum aborsi sebelum ruh ditiupkan ke dalam janin. Ada kalangan yang membolehkannya secara mutlak, seperti sebagian pengikut Abu Hanifah yang menyatakan aborsi dibolehkan selama ruh belum ditiupkan ke dalam janin (al-Takhalluq).

Menurut pengikut Imam Malik, Al-Lakhmi, proses al-Takhalluq terjadi sebelum janin berumur empat puluh hari. Pendapat serupa juga dikemukakan oleh Abu Ishaq al-Marwaji, seorang pengikut Imam Syafi'i. Al-Ramli mengatakan, apabila sperma di dalam rahim adalah hasil zina maka boleh digugurkan selama ruh belum ditiupkan. Dalam hal ini pengguguran atau melakukan aborsi akibat dari perkosaan menurut saya tidak memberikan solusi yang tepat karena dalam hal ini janin yang dikandung mempunyai hak untuk hidup karena secara kedaruratan medis memang tidak membahayakan nyawa sang ibu dan anak seharusnya tetap dilahirkan dengan kondisi apapun karena anak adalah titipan untuk kita dari sang maha pencipta dan itu harus dijaga dan tidak boleh disia-siakan apalagi sampai dibunuh karena satu sisi si ibu tidak menginginkannya.

Praktik aborsi baik yang dilakukan oleh pihak yang berkompeten atau dukun ataupun yang dilakukan oleh pihak-pihak yang tidak memiliki kompetensi sehingga menimbulkan bahaya bagi ibu yang mengandungnya dan bagi masyarakat umumnya. Fenomena tersebut menimbulkan banyak pertanyaan dari masyarakat tentang hukum melakukan aborsi, apakah haram secara mutlak ataukah boleh hukumnya dalam kondisi-kondisi tertentu .

Janin yang berada dalam kandungan ibunya tidak dianggap manusia hidup dari segala sisi. Dalam hukum Islam, janin disebut sebagai jiwa pada 
satu sisi dan bukan jiwa pada sisi yang lain. Barangsiapa membunuh janin maka ia tidak dianggap sebagai pembunuh yang sengaja, tetapi sebagai pelaku pembunuhan jenis tertentu dan berhak mendapat hukuman tertentu pula. ${ }^{8}$ Aborsi tidak terlepas dari kondisi sebelum ditiupkan ruh ke janin selama seratus dua puluh (120) hari, yaitu empat bulan pertama kehamilan, atau sesudahnya, dan bahwa unsur dalam aborsi dianggap sebuah tindak kejahatan yang mengakibatkan hukuman, karena aborsi ini menghilangkan nyawa anak adam yang hidup.

Ada dalil tentang haramnya menghilangkan nyawa anak Adam di dalam kitab sunnah dan ijma ulama. ${ }^{9}$

Dalil dalam Alquran, antara lain:

"Dan janganlah kamu membunuh jiwa yang diharamkan Allah (membunuhnya), melainkan dengan suatu (alasan) yang benar. Dan barang siapa dibunuh secara dzalim, maka sesungguhnya kami telah memberi kekuasaan kepada ahli warisnya, tetapi janganlah ahli waris itu melampaui batas dalam membunuh. Sesungguhnya adalah orang yang mendapat pertolongan. “ (Qs. Al Isra' 17: 33)

Di dalam teks-teks Al-Qur'an dan Hadits tidak didapati secara khusus hukum aborsi, tetapi yang ada adalah larangan untuk membunuh jiwa orang tanpa hak, sebagaimana firman Allah SWT:

“Dan barang siapa yang membunuh seorang mukmin dengan sengaja, maka balasannya adalah neraka Jahanam, dan dia kekal di dalamnya, dan Allah murka kepadanya dan melaknatnya serta menyediakan baginya adzab yang besar( QS An Nisa' [4] : 93 )

Begitu juga hadist dari Ibnu Mas'ud yang diriwayatkan oleh Bukhari dan Muslim bahwasannya Rosulullah SAW bersabda:

“Sesungguhnya seseorang dari kamu dikumpulkan penciptaannya di dalam perut ibunya selama empat puluh hari. Setelah genap empat puluh hari kedua, terbentuklah segumpal darah beku. Ketika genap empat puluh hari ketiga, berubahlah menjadi segumpal daging. Kemudian Allah mengutus malaikat untuk meniupkan roh, serta memerintahkan untuk menulis empat

8 Abdul Qadir Audah, Ensiklopedia Hukum Pidana Islam II, (PT. Kharisma Ilmu), ( AtTasyri' al-Jinaiy al-Islamiy Muqaranan bil Qanunil Wad'iy, Bab Aborsi ), h 185

9 Abbas Syauman, Hukum Aborsi Dalam Islam, (Jakarta: Cendekia Sentra Muslim Anggota IKAPI), 2004, cetakan pertama, h. 45 
perkara, yaitu penentuan rizki, waktu kematian, amal, serta nasibnya, baik yang celaka, maupun yang bahagia. ${ }^{10}$

Memang bicara mengenai aborsi tidak dapat dilihat hanya dari satu sudut pandang saja karena ini merupakan persoalan yang sangat kompleks dan tidak berdiri sendiri, sama halnya dengan persoalan-persoalan kemanusiaan lainnya. Para ulama sepakat bahwa hukum asal aborsi adalah haram. Meski demikian masih terbuka celah untuk diperbolehkan aborsi dengan alasan yang cukup kuat. ${ }^{11}$

Sejak awal dikatakan bahwa meskipun aborsi kini merupakan topik yang sangat kontroversial. Presiden RI melalui PP. No 61 tahun 2014 tentang kesehatan reproduksi menghalalkan aborsi akibat pemerkosaan. Hal ini cukup mengagetkan banyak pihak, khususnya para ulama dan kaum muslimin yang selama ini berpandangan bahwa aborsi itu hukumnya haram. Penghalalan aborsi ini dapat dilihat pada pasal 31 PP ayat (1) yang berbunyi: tindakan aborsi hanya dapat dilakukan berdasarkan a) indikasi kedaruratan medis; atau b) kehamilan akibat pemerkosaan. Selanjutnya ayat (2) pasal ini menyatakan tindakan aborsi akibat perkosaan sebagaimana dimaksud pada ayat (1) huruf b hanya dapat dilakukan apabila usia kehamilan paling lama berusia 40 (empat puluh) hari dari sejak hari pertama haid terakhir. ${ }^{12}$

Berdasarkan yang telah tertuang dalam latar belakang di atas, maka penulis bermaksud melakukan kajian dan penelitian tentang "Aborsi Akibat Pemerkosaan dan Kedaruratan Medis Menurut Hukum Islam (Analisis PP No. 61 Tahun 2014 Tentang Kesehatan Reproduksi)".

\section{Pengertian Aborsi Menurut Hukum Islam}

Pada bab sebelumnya telah dijelaskan bahwa Islam tidak mendukung aborsi (pengguguran janin) dengan alasan kehamilannya tidak diharapkan. Bab ini secara khusus akan membahas rujukan-rujukan terhadap aborsi dalam literatur hukum Islam dan rujukan-rujukan dari dokter Islam, dengan tujuan

10 Imam Muslim, Shahih Muslim. (Beirut: Dar El Fiker, 1993. Hadis 2643, jilid 2, h. 412). Lihat juga hadis 2645, h. 414.

11 Abbas Syauman, Hukum Aborsi Dalam Islam, (Jakarta: Cendekia Sentra Muslim Anggota IKAPI), 2004, cetakan pertama, h 16

12 M Nurul Irfan, (Gratikasi Dan Kriminalitas Seksual Dalam Hukum Pidana Islam), (Jakarta: Amzah, 2014), cetakan pertama, h. 104 
menetapkan alasan-alasan yang secara umum dapat diterima sebagai alasan sah dilakukannya aborsi. ${ }^{13}$

Pada umumnya hukum aborsi dalam Islam adalah tidak diperbolehkan (haram). Islam menginginkan agar keturunan para pengikutnya terus berkembang. Karena ketika sperma dan sel telur telah bercampur sehingga membentuk embrio, maka ini merupakan awal kehidupan. ${ }^{14}$ Sebagaimana di firmankan dalam Surat Al-Insan [76] : 2

"Sesungguhnya Kami telah menciptakan manusia dari setetes mani yang bercampur yang Kami hendak mengujinya (dengan perintah dan larangan), karena itu Kami jadikan dia mendengar dan melihat.(QS. Al-Insan [76]: 2)

Aborsi secara kebahasaan berarti keguguran kandungan atau membuang janin. ${ }^{15}$ Sedang makna gugurnya kandungan, menurut para fuqaha tidak keluar jauh dari makna lughowinya, akan tetapi kebanyakan mereka mengungkapkan istilah ini di beberapa tempat dengan istilah arab: isqath (menjatuhkan), thar (membuang), ilqa (melempar), dan imlash (melahirkan dalam keadaan mati). ${ }^{16}$

Pengertian menggugurkan kandungan dibatasi pada lahirnya janin karena dipaksakan oleh ibunya atau dipaksakan oleh orang lain atas permintaan dan kerelaannya. ${ }^{17}$ Ulama fiqh kontemporer sebelum membahas hukum aborsi terlebih dahulu mengemukakan pembahasan tentang proses kejadian manusia di dalam rahim. Dalam Surah Al-Mu'minun 23 : 12-14

(QS. Al-Mu'minun[23]: 12-14)

"Dan sesungguhnya Kami telah menciptakan manusia dari suatu saripati (berasal) dari tanah. Kemudian Kami jadikan saripati itu air mani (yang disimpan) dalam tempat yang kokoh (rahim). Kemudian air mani itu Kami jadikan segumpal darah, lalu segumpal darah itu Kami jadikan segumpal

${ }_{13}$ Abul Fadl Mohsin Ebrahim, Aborsi Kontrasepsi dan Mengatasi Kemandulan (Isu-isu Biomedis Dalam Perspektif Islam. (Bandung : Penerbit Mizan Anggota IKAPI, 1997), h. 156

${ }^{14}$ Ibrahim Amini, Anakmu Amanatnya Buah Sebagai Sekolah Utama, (Jakarta: Al-Huda, 2006), Cetakan Pertama, h. 62

Cet .1, hlm, 7

${ }^{15}$ Hafiz Dasuki, Ensiklopedi Hukum Islam, (Jakarta: PT Ichtiar Baru Van Hoeve, 1997),

${ }^{16}$ M. Nu"aim Yasin, Fiqih Kedokteran, (Jakarta : Pustaka Al -Kautsar, 2001), Cet. Ke-III, h. 229

17 Saifullah, Aborsi dan Permasalahannya: Suatu Kajian Hukum Islam dalam Chuzaimah, T. Yanggo (ed), et, Al, buku kedua problematika Hukum Islam kontemporer 
daging, dan segumpal daging itu Kami jadikan tulang belulang, lalu tulang belulang itu Kami bungkus dengan daging. Kemudian Kami jadikan dia makhluk yang (berbentuk) lain. Maka Maha sucilah Allah, Pencipta Yang Paling Baik". (QS. Al-Mu'minun[23]: 12-14)

Yang dimaksud dengan nutfah (air mani) dalam ayat 13 dan 14 dari surah al-mukminun 23 adalah tahapan pertama dari kejadian manusia, bukan cairan kental yang memancar dari kelamin laki-laki ketika terjadi ejakulasi. Karena jika nutfah diartikan sebagai cairan kental dari kelamin laki-laki atau air mani saja, hal tersebut tidak menunjukkan tahapan kejadian manusia. Oleh sebab itu, pengertian yang tepat tentang nutfah adalah hasil pembuahan setelah terjadinya pertemuan sperma dan ovum dalam rahim. Demikian pula alaqah' diartikan sebagai segumpal darah dan tahapan kedua dari proses penciptaan manusia. Sedangkan mudgah sebagai tahapan ketiga dari proses kejadian manusia lebih tepat diartikan sebagai embrio yang berproses menjadi calon bayi yang lengkap anggota tubuhnya, bukan sekedar segumpal daging. ${ }^{18}$

Para fuqaha (Ahli Hukum Islam) sepakat mengatakan bahwa pengguguran kandungan (aborsi) sesudah ditiupkan ruh (setelah 4 bulan kehamilan) adalah haram, tidak boleh dilakukan, karena perbuatan tersebut merupakan kejahatan terhadap nyawa. Sedangkan pengguguran kandungan sebelum ditiupkan ruh pada janin (embryo) yaitu sebelum berumur 4 bulan, para fuqaha berbeda pendapat tentang boleh tidaknya melakukan pengguguran tersebut. ${ }^{19}$

Maka Islam jelas melarangnya, karena pada hakikatnya aborsi sama dengan merusak atau menghancurkan janin calon manusia yang dimuliakan oleh Allah, karena ia berhak lahir dalam keadaan hidup, sekalipun eksistensinya hasil dari hubungan yang tidak sah (di luar perkawinan yang sah). Sebab menurut Islam bahwa setiap anak yang lahir, adalah seseorang yang sudah mempunyai hak dan dalam keadaan suci (tidak berdosa). ${ }^{20}$ Sesuai dengan Hadis Nabi Muhammad SAW: "Setiap anak yang lahir dilahirkan di atas fitrah, maka kedua orang tuanya lah yang menjadikan Nasrani dan Yahudi".

${ }_{18}$ Abdul Azis Dahlan, Ensiklopedia Hukum Islam, (Jakarta: PT. Ichtiar Baru Van Hoeve, 1996), cet 1 , h. 8

${ }^{19}$ Maria Ulfa Anshor, dkk. (Aborsi dalam Perspektif Figh Kontemporer), (Jakarta : Balai Penerbit Fakultas Kedokteran Indonesia, 2002), h. 110

${ }^{20}$ Masjfuk Zuhdi, Masail Fighiyyah Kapita Selekta Hukum Islam, (Jakarta: PT. Toko Gunung Agung, 1997), h. 83 
Yang dimaksud dengan fitrah dalam Hadits tersebut ada dua pengertian menurut Masjfuk Zuhdi dalam buku Masail Fiqhiyyah Kapita Selekta Hukum Islam, yaitu:21

Pertama; Dasar pembawaan manusia (Human Nature) yang religius dan monotheis, artinya bahwa manusia dari dasar pembawaannya adalah makhluk yang beragam dan percaya pada kekuasaan Allah secara murni/pure monotheisme atau tauhid khalish. Hal ini sesuai dengan firman Allah SWT ( QS. Al A'raf [7] : 172 )

"Dan (ingatlah), ketika Tuhanmu mengeluarkan keturunan anak-anak Adam dari sulbi mereka dan Allah mengambil kesaksian terhadap jiwa mereka (seraya berfirman): "Bukankah Aku ini Tuhan kami), kami menjadi saksi". (Kami lakukan yang demikian itu) agar di hari kiamat kamu tidak mengatakan: "Sesungguhnya kami (Bani Adam) adalah orang-orang yang lengah terhadap ini (Ke-Esaan Tuhan)". (QS.Al-A'raf 7:172)

Ayat tersebut menunjukan, bahwa manusia sebelum turun ke bumi, telah mengakui keTuhanan Allah dan Kekuasaanya.

Kedua; Kesucian (purity), artinya bahwa semua anak manusia dilahirkan dalam keadaan suci/bersih dari segala macam dosa. Hal ini sesuai dengan firman Allah ( Q.S An-Najm [53] : 38): "Bahwasanya seorang yang berdosa tidak akan memikul dosa orang lain”. (QS. An-Najm [35]:38)

Dalam kitab fikih yang membahas masalah aborsi yang dikutip oleh Maria Ulfa Anshor, Wan Nedra dan Sururi dalam buku mereka yaitu Aborsi dalam Perspektif Fikih Kontemporer maka ditemukan tiga istilah yang dapat dikategorikan dalam pengertian aborsi:

a. Isqath al-haml: Yang dimaksud dengan isqath al-haml adalah gugurnya janin dari perut ibunya, atau gugurnya sesuatu dari perut ibu (perempuan).

Dari pengertian pertama memunculkan pertanyaan: Apakah yang dimaksud dengan janin? Adapun yang dianggap sebagai janin adalah setiap sesuatu yang keluar dari rahim seorang perempuan yang diketahui bahwa sesuatu itu adalah anak manusia. ${ }^{22}$ Dalam pengertian lainnya juga disebutkan,

${ }^{21}$ Masjfuk Zuhdi, Masail Fiqhiyyah Kapita Selekta Hukum Islam, (Jakarta: PT. Toko Gunung Agung, 1997), h. 84

22 Ahmad Wardi Muslich, Hukum Pidana Islam, (Jakarta: Sinar Grafika, 2005), cetakan pertama, h. 222 
bahwa janin adalah anak yang berada dalam rahim ibu setelah usia 8 (delapan) minggu. "Oleh sebab itu yang dimaksud dengan hamil adalah setelah usia kandungan delapan minggu".

b. Al- Ijhadh: "Yaitu gugurnya anak yang belum sempurna".

Dalam pengertian ini secara jelas disebutkan bahwa yang gugur adalah anak, akan tetapi belum sempurna wujud dari anak tersebut. Sempurna dalam hal ini yaitu diciptakan dalam bentuknya yang paling sempurna sebagaimana tertuang dalam surat At-Tin. "Sesungguhnya Kami telah menciptakan manusia dalam bentuk yang sebaik-baiknya". (QS. At-Tin [95]: 4)

c. Al-Imlash: "Yaitu janin yang lahir dan mati, apakah itu sengaja atau tidak".

Maksudnya adalah apabila janin gugur dalam keadaan hidup tetapi kemudian ia meninggal akibat perbuatan pelaku, menurut pandangan ulama dalam buku Hukum Pidana Islam karangan Ahmad Wardi Muslich menyatakan adanya kesengajaan, hukumannya adalah qishash dan apabila janin gugur dalam keadaan hidup dan ia tetap bertahan dalam hidupnya, atau kemudian ia meninggal karena sebab lain, hukuman bagi pelaku adalah hukuman $t a^{\prime} z i r{ }^{23}$

\section{Macam-macam Aborsi}

Secara umum, pengguguran kandungan dapat dibagi menjadi dua macam yaitu:

Pertama; Abortus spontan (spontaneus abortus) yaitu abortus yang tidak sengaja. Abortus spontan ini terjadi karena sebab-sebab alamiah, bukan karena perbuatan manusia. Abortus spontan ini biasanya terjadi pada tiga bulan pertama dari masa kehamilan dan tidak ada suatu pencegahan pun yang dapat menghindarkan penyebab umum keguguran ini, bahkan dokter juga tidak dapat menentukan dengan tepat apa yang menyebabkannya. Biasanya abortus seperti ini diawali dengan pendarahan tanpa diketahui sebabnya. Tetapi adapula yang terjadi, kerena terkejut atau jatuh. Abortus

${ }^{23}$ Ahmad Wardi Muslich, Hukum Pidana Islam, (Jakarta: Sinar Grafika, 2005), cetakan pertama, h. 225 
semacam ini, tidak menimbulkan dampak hukum, karena hal itu terjadi, di luar kehendak dan kuasa manusia. ${ }^{24}$

Menurut tingkat proses/ilmu kedokteran, dikenal beberapa tahap abortus, yaitu:

a) Abortumenes, yaitu keadaan dimana masih ada kemungkinan kehamilan bisa diselamatkan.

b) Abortus Insipeins, yaitu suatu keadaan dimana keguguran tidak mungkin dicegah.

c) Abortus Imkompletus, yaitu keadaan keguguran tetapi masih tertinggal sisa-sisa buah kehamilan di dalam rongga rahim.

d) Abortus Complectus, yaitu pengeluaran secara keseluruhan janin dari rahim. ${ }^{25}$

e) Abortus Imminens yaitu ancaman terjadinya abortus, ditandai perdarahan per vaginam(lewat vagina), ostium uteri masih tertutup dan hasil konsepsi masih baik dalam kandungan.

f) Abortus Habitualis adalah kejadian abortus berulang pada 3 kehamilan atau lebih berturut - turut. Abortus habitualis umumnya disebabkan karena kelainan anatomik uterus (mioma, septum, serviks inkompeten, dll), atau kelainan faktor-faktor imunologi. Pada kasus abortus habitualis perlu dilakukan pemeriksaan USG untuk melihat ada atau tidaknya kelainan anatomi. Selain itu juga perlu dilakukan rangkaian pemeriksaan faktor-faktor hormonal/imunologi/ kromosom.

g) Missed Abortiom yaitu embrio/fetus meninggal dalam kandungan dan masih tertahan dalam kandungan. Biasanya didahului tanda dan gejala abortus imminens yang kemudian menghilang spontan atau menghilang setelah pengobatan.

Penanganan: mengeluarkan jaringan konsepsi dengan stimulasi kontraksi uterus. Jika dilakukan tindakan kuretase, maka harus sangat hati-

${ }^{24}$ M. Ali Hasan, Masail Fiqhiyyah Al- Haditsah Pada Masalah-Masalah Kontemporer Hukum Islam, (Jakarta: PT Raja Grafindo Persada, 2000 ), Cet 4, h. 46

${ }_{25}$ Yudho Prasetyo, Penyalahgunaan Obat Sebagai Alat Penggugur Kandungan Dalam Perspektif Hukum Pidana Indonesia dan Hukum Pidana Islam, (Jakarta: UIN, 2015), h. 31 
hati karena jaringan telah mengeras, dan dapat terjadi gangguan pembekuan darah akibat komplikasi kelainan koagulasi (hipofibrinogenemia). ${ }^{26}$

Kedua; Abortus Provocantus/Inducet pro Abortion/pengguguran kandungan dengan sengaja.

Menurut tujuannya abortus provocatus dibedakan menjadi dua macam ialah :

a) Abortus provocatus Medisinalis/abortus artificialid therapicius. Yaitu abortus yang dilakukan oleh dokter atas dasar indikasi medis. Dengan kata lain sesuai dengan pemeriksaan medis yang menunjukkan adanya gejala-gejala membahayakan jiwa si ibu. Tindakan medis ini diambil sebagai penyelamatan terhadap jiwa si ibu yang sedang mengandung dan terancam keselamatannya apabila kehamilannya diteruskan.

b) Abortus provocatus Criminalis, yaitu aborsi yang dilakukan tanpa dasar indikasi medis. Hal ini biasanya dilakukan untuk menghilangkan jejak hasil hubungan seks di luar nikah atau menghilangkan kehamilan yang tidak dikehendaki, baik karena pertimbangan ekonomi maupun akibat pergaulan bebas. Aborsi pada bentuk ini biasanya dilakukan secara ilegal. ${ }^{27}$

Abortus jenis ini disebut juga terminasi kehamilan, yang mempunyai dua macam yakni:

\section{a) Bersifat legal}

Aborsi legal dilakukan oleh tenaga kesehatan atau tenaga medis yang berkompeten berdasarkan indikasi medis, dan dengan persetujuan ibu yang hamil dan atau suami. Aborsi legal sering disebut juga aborsi buatan atau pengguguran kandungan dengan indikasi medis. Meskipun demikian, tidak setiap tindakan aborsi yang sudah mempunyai indikasi medis ini dapat dilakukan aborsi buatan. Persyaratan yang lain harus dipenuhi sebuah aborsi adalah:

- Aborsi hanya dilakukan sebagai tindakan teraputik

- Disetujui secara tertulis oleh dua orang dokter yang berkompeten

${ }^{26}$ Definisiaborsihttp://macammacampenyakitkandungandanabortus.blogspot.co.id/201 3/06pengertian-dan-macam-macam-abortus.html. Diakses pada tanggal 04 februari 2016

${ }^{27}$ Wiknjosastro, dkk, Aborsi Dalam Perspektif Figh Kontemporer, (Jakarta: Buku Kompas, 2006), h. $75-76$ 
- Dilakukan ditempat pelayanan kesehatan yang diakui oleh suatu otoritas yang sah

\section{b) Bersifat Ilegal}

Aborsi ilegal dilakukan oleh tenaga kesehatan atau tenaga medis yang tidak berkompeten, melaui cara-cara di luar medis (pijat, jamu atau ramuanramuan), dengan atau tanpa persetujuan ibu hamil dan atau suaminya. Aborsi illegal sering juga dilakukan oleh tenaga medis yang berkompeten, tetapi tidak mempunyai indikasi medis. ${ }^{28}$

Secara umum ada dua cara yang dilakukan untuk mencegah terjadi praktek abortus, yaitu:

1). Melalui upaya hukum

Cara ini dapat dilakukan dengan mengeluarkan undang-undang abortus, dengan memberikan bimbingan dan penyuluhan hukum kepada masyarakat luas, yang dilkuakan oleh badan penegak hukum atau instansi terkait lainnya.

2). Melalui gerakan sosial keagamaan

Dalam hal ini peran kaum ulama dan para dai sangat berpengaruh, terutama bagi umat Islam. Mereka dapat menyadarkan umat untuk tidak melakukan perbuatan keji, karena perbuatan itu tidak hanya mendapat sanksi hukum di dunia ini, tetapi di akhirat kelak akan mendapat azab dari Allah SWT. ${ }^{29}$

Cara-cara menggugurkan kandungan sangat beragam karena banyaknya sebab-sebab keguguran. Cara pengguguran kandungan dapat dibedakan menjadi 3 bagian:

$\checkmark$ Cara aktif, dalam hal ini pengguguran kandungan terjadi karena adanya satu aksi, baik berasal dari ibu ataupun orang lain. Sebagai contoh terjadinya kejahatan seperti pemukulan yang berdampak dari ibu atau janinnya saja.

${ }^{28}$ Soekidjo Notoatmodjo, Etika dan Hukum Kesehatan, (Jakarta : Rineka Cipta, 2010), h. 136

${ }^{29}$ M. Ali Hasan, Masail Fiqhiyyah Al- Haditsah Pada Masalah-Masalah Kontemporer Hukum Islam, (Jakarta: PT Raja Grafindo Persada, 2000 ), Cet 4, h.50 
$\checkmark$ Cara Pasif, suatu cara yang tidak mau melakukan sesuatu yang penting bagi keberlangsungan kehamilannya sehingga menyebabkan bahaya pada kehamilannya. Contoh ibu tidak mau mengkonsumsi obat-obatan yang telah diresepkan oleh dokter.

$\checkmark$ Cara medis, yaitu pengguguran kandungan yang digunakan oleh dokter, antara lain menyuntikkan anti zat progesteron yang berfungsi menguatkan kehamilan, menggunakan zat prostagelamizin yang membunuh janin dengan cara menyuntikkan pada pembulu darah atau urat atau rahim, dan menggunakan obat misoprostol secara diminum dengan efek samping menyebabkan kontraksi pada rahim sehingga janin keluar dari rahim. ${ }^{30}$

Dalam literatur fikih, macam-macam aborsi dapat digolongkan menjadi lima macam di antaranya: ${ }^{31}$

a. Aborsi spontan (al-isqath al-dzaty)

Aborsi spontan (al-Isqath al-Dzaty), artinya janin gugur secara alami tanpa adanya pengaruh dari luar, atau gugur dengan sendirinya. Kebanyakan aborsi spontan disebabkan oleh kelainan kromoson, hanya sebagian kecil disebabkan oleh infeksi, kelainan rahim serta kelainan hormon. Kelainan bibit atau kromosom tidak memungkinkan mudgah untuk tumbuh normal, kalaupun kehamilan berlangsung, maka janin yang akan lahir dengan cacat bawaan.

b. Aborsi karena darurat atau pengobatan (al-Isqath al-Dharury/al-illajiy)

Aborsi karena darurat atau pengobatan (al-isqath al-dharury/al-illajiy), misalnya aborsi dilakukan karena adanya indikasi fisik yang mengancam nyawa ibu bila kehamilannya dilanjutkan.

c. Aborsi karena khilaf atau tidak sengaja (khata')

Aborsi dilakukan karena khilaf atau tidak sengaja (khata'), misalnya seorang petugas kepolisian tengah memburu pelaku tindak kriminal di suatu

${ }^{30}$ Andhika Yudho Prasetyo, (Penyalahgunaan Obat Sebagai Alat Penggugur Kandungan Dalam Perspektif Hukum Pidana Indonesia dan Hukum Pidana Islam, 2015), (Fakultas Syariah dan Hukum, UIN Syarifhidayatullah Jakarta), h. 33-34

${ }^{31}$ Goelardi Wignjosastro, "Masalah Kehidupan dan Perkembangan Janin", Aborsi dari Perspektif Fiqih Kontemporer, Jakarta, 28 April 2001. PP Fatayat NU dan The Ford Foundation dalam Maria Ulfa Anshor, Fiqih Aborsi: Wacana Penguatan hak Reproduksi Perempuan, (Jakarta: Buku Kompas, 2006), cetakan pertama, h. 38 
tempat yang ramai pengunjung. Karena takut jejak, polisi berusaha menembak penjahat tersebut, tetapi pelurunya nyasar ke tubuh ibu hamil sehingga menyebabkan ia keguguran. hal serupa juga bisa terjadi, ketika seorang polisi hendak memperkarakan tindak kriminal yang dilakukan oleh seorang yang tengah hamil karena ia takut, stres berat, dan jiwanya guncang sehingga mengakibatkan keguguran tindakan polisi tersebut merupakan tindakan tidak sengaja (khata')

d. Aborsi yang menyerupai kesengajaan (syibh'amd)

Aborsi dilakukan dengan cara menyerupai kesengajaan (syibh'amd), misalnya seorang suami menyerang istrinya yang tengah hamil muda hingga mengakibatkan ia keguguran. Dikatakan menyerupai kesengajaan karena serangan tidak ditujukan langsung pada janin, tetapi pada ibunya. Kemudian akibat serangan tersebut, janin terlepas dari tubuh ibunya atau keguguran. Menurut fikih pihak penyerang harus diberi hukuman, dan hukuman semakin berat jika janin ketika keluar dari perut si ibu sempat memberikan tanda-tanda kehidupan, misalnya menagis atau bergerak-gerak.

e. Aborsi sengaja dan terencana (al-'amd)

Aborsi dilakukan secara sengaja dan terencana (al-'amd). Misalnya seorang ibu sengaja meminum obat dengan maksud agar kandungannya gugur, atau ia sengaja menyuruh orang lain (dokter, dukun, dan sebagainya) untuk menggugurkan kandungannya. ${ }^{22}$

\section{Aborsi Menurut Pandangan Ulama Mazhab}

Dalam istilah syariat Islam dikenal ada empat istilah atau kriteria pengguguran kandungan yang kiranya perlu diketahui sebelum memasuki bahasan persoalan aborsi lebih lanjut.

1. Pengguguran direncanakan atau dengan sengaja (bil-amdi), misalnya si ibu dengan sengaja meminum obat-obatan agar bayi yang dikandungnya menjadi gugur. Atau bisa juga ia menyuruh orang lain misalnya dokter untuk membantu proses dan kelancaran pengguguran yang diinginkan.

32 Maria Ulfa Anshor, Fikih Aborsi (Wacana Penguatan Hak Reproduksi Perempuan). (Jakarta: Buku Kompas, 2006), Cetakan pertama, h. 38-40 
2. Terdapat unsur-unsur atau menyerupai kesengajaan syibhul amdi misalnya si ibu melakukan pekerjaan-pekerjaan berat yang berbahaya yang secara tidak langsung bisa mempengaruhi keberadaan janin dalam kandungan, misalnya ia melakukan olahraga sepeda gunung padahal pekerjaan itu harus dihindari.

3. Kekhilafan atau tak sengaja (khatha'), yaitu pengguguran kandungan akibat serangan brutal dari orang lain terhadap ibu hamil. Serangan tersebut memang secara langsung diarahkan kepada janin, jadi akibat kebrutalan serangan tersebut janin menjadi gugur.

4. Janin gugur sendiri, yang dalam istilah bahasa populer disebut sebagai keguguran. Keguguran seperti ini terbebaskan dari sanksi hukum, karena keguguran janin tersebut bukan akibat kejahatan yang dilakukan oleh tangan-tangan manusia.

Menurut sebagian besar Ulama Fikih, pengguguran kandungan/ aborsi yang dilakukan dengan cara seperti yang terdapat pada nomor satu sampai dengan tiga maka pelakunya diwajibkan membayar al-ghurrah (uang kompensasi). Dalam hal ini yang diperselisihkan adalah batas usia janin. Sebagian ulama berpendapat bahwa al-ghurrah harus dikeluarkan dan dibayarkan walaupun usia janin belum memasuki masa peniupan ruh (qabla nafkhir ruh), sementara yang lain mengatakan bahwa al-ghurrah baru dibebankan kepada pelaku pengguguran jika usia janin lewat dari empat puluh bulan (120 hari), atau (ba'da nafkhir ruh). ${ }^{33}$

Kalangan fuqaha sepakat, hukuman al-ghurrah wajib diberlakukan ketika kematian janin disebabkan oleh permusuhan, atau ketika janin sudah dalam keadaan tidak bernyawa saat terpisah dari rahim si ibu, atau ketika janin baru terpisah sebagian dari rahim sang ibu dan ada tanda-tanda kalau janin sudah mati. ${ }^{34}$

Batasan setelah pemberian ruh atau setelah 120 hari tersebut adalah Al-Quran yaitu:

${ }_{33}$ Maria Ulfa Anshor, dkk. (Aborsi Dalam Perspektif Figh Kontemporer), (Jakarta: Balai Penerbit Fakultas Kedokteran Indonesia, 2002), h. 229

${ }^{34}$ Abd al-Qadir Manshur, Buku Pintar Fikih Wanita (Segala Hal Yang Ingin Anda Ketahui Tentang Perempuan dalam Hukum Islam), (Jakarta: Zaman, 2009), cetakan pertama, h 119 
“Dan sesungguhnya Kami telah menciptakan manusia dari suatu saripati (berasal) dari tanah. (13) Kemudian Kami jadikan saripati itu air mani (yang disimpan) dalam tempat yang kokoh (rahim). 14 Kemudian air mani itu Kami jadikan segumpal darah, lalu segumpal darah itu Kami jadikan segumpal daging, dan segumpal daging itu Kami jadikan tulang belulang, lalu tulang belulang itu Kami bungkus dengan daging. Kemudian Kami jadikan dia makhluk yang (berbentuk) lain. Maka Maha sucilah Allah, Pencipta Yang Paling Baik.

Selain itu didasarkan pada Hadist empat puluhan.

“Tiap-tiap dari kamu sekalian berada dalam rahim ibumu selama empat puluh hari berupa nuthfah (air mani), kemudian menjadi 'alaqah (segumpal darah) selama periode yang sama, kemudian mudghah (segumpal daging) selama peride yang sama juga, kemudian malaikat diutus, dan dia meniupkan ruh ke dalamnya ..." (HR. Bukhari-Muslim).

Beberapa pendapat Mazhab tentang aborsi yaitu sebagai berikut:

\section{a. Madzhab Hanafi}

Aborsi pada umumnya diizinkan sebelum 120 hari ketika janin telah mencapai tahap menjadi suatu makhluk baru (yakni, mereka merujuk pada penyawaan). Sebagian memandangnya tidak disukai tanpa alasan yang sah, karena begitu dikandung, janin mempunyai potensi untuk hidup. Salah satu indikasi yang paling jamak dikutip dalam mazhab ini ialah bilamana si wanita hamil saat sedang menyusui anaknya dan susunya berhenti, sementara si ayah tidak mempunyai sumber pendapatan untuk menyediakan susu pengganti. Ini dibenarkan untuk memelihara kehidupan si anak yang sedang menyusu. ${ }^{35}$

Sebagian besar dari fukaha Hanafiyah berpendapat bahwa aborsi diperbolehkan sebelum janin terbentuk. Tepatnya membolehkan aborsi sebelum ditiupkannya ruh, tetapi harus disertai dengan syarat-syarat yang rasional, meskipun kapan janin terbentuk masih menjadi hal yang ikhtilaf. Janin dianggap memiliki jiwa ketika terlihat layak menerima hak dan dianggap tidak memiliki jiwa ketika terlihat tidak pantas menerima hak. ${ }^{36}$

35 'Abd al-Rahim 'Umran, Islam dan KB (Jakarta: PT. LENTERA BASRITAMA Anggota IKAPI, 1992), cetakan pertama, h. 232

${ }^{36}$ Abdul Qadir Audah, Ensiklopedia Hukum Pidana Islam II, ( At-Tasyri' al-Jinaiy alIslamiy Muqaranan bil Qanunil Wad'iy, Bab Aborsi ), (Jakarta: PT. Kharisma Ilmu, diterjemahkan oleh Tim Salsilah, 2006), h. 185 


\section{b. Madzhab Maliki}

Ulama Malikiyah berpandangan bahwa kehidupan sudah di mulai sejak konsepsi. Oleh karena itu, menurut mereka, aborsi tidak diizinkan bahkan sebelum janin berusia 40 hari kecuali Al-Lakhim yang membolehkan aborsi sebelum janin berusia 40 hari. Hal tersebut ditemukan dalam Hasyiaah AL-Dasuki bahwa tidak diperbolehkan melakukan aborsi bila air mani telah tersimpan dalam rahim, meskipun belum berumur 40 hari begitu juga menurut Al-Laisy, jika rahim telah menangkap air mani, maka tidak boleh suami istri ataupun salah satu dari mereka mengguggurkan janinnya, baik sebelum penciptaan maupun sesudah penciptaan. ${ }^{37}$

\section{c. Madzhab Syafi'i}

Ulama-ulama Syafi'iyah berselisih pendapat mengenai aborsi sebelum 120 hari. Ada yang mengharamkan seperti Al-`Imad, ada pula yang membolehkan selama masih berupa sperma atau sel telur (nutfah) dan segumpal darah (alaqah) atau berusia 80 hari sebagaimana di katakan Muhammad Abi Sad, namun ulama lain membolehkan sebelum janin berusia 120 hari, atau sebelum janin di beri roh. Namun, sebagian besar dari fukaha Syafi'iyah menyepakati bahwa aborsi haram sebelum usia kehamilan 40-42 hari.

Imam Al-Ghazali mengatakan bahwa kehidupan telah dimulai sejak pertemuan antara air sperma dengan ovum di dalam rahim perempuan. Jika telah ditiupkan ruh kepada janin, maka itu merupakan tindak pidana yang sangat keji, setingkat dibawah pembunuhan bayi hidup-hidup. ${ }^{38}$

\section{d. Madzhab Hanbali}

Dalam pandangan Jumhur Ulama Hanabilah, janin boleh digugurkan selama masih dalam fase segumpal daging (mud-ghah), karena belum berbentuk anak manusia, sebagaimana ditegaskan Ibnu Qudamah dalam kitab al-Mughni

" Pengguguran terhadap janin yang masih berbentuk mudgah dikenai denda (ghurrah), bila menurut tim spesialis ahli kandungan janin sudah terlihat bentuknya. Namun, apabila baru memasuki tahap pembentukan, dalam hal

37 Maria Ulfa Anshor, Fikih Aborsi (Wacana Penguatan Hak Reproduksi Perempuan). (Jakarta: Penerbit Buku Kompas, 2006), Cetakan pertama, h. 93

${ }^{38}$ Al- Musayyar, Sayid Ahmad, Islam Berbicara Soal Seks, Percintaan, Dan Rumah Tangga, Cairo : PT. Gelora Aksara Pratama, 2008, h. 82 
ini ada dua pendapat; pertama yang paling shahih adalah pembebasan hukuman ghurrah, karena janin belum terbentuk misalnya baru berupa alaqah, maka pelakunya tidak dikenai hukuman, dan pendapat kedua; ghurrah tetap wajib karena janin yang digugurkan sudah memasuki tahap penciptaan anak manusia".

\section{Sanksi Tindak Pidana Aborsi Menurut Hukum Pidana Islam}

Para fuqaha sepakat bahwa aborsi setelah ditiupkannya ruh adalah haram dan merupakan kejahatan, akan tetapi apabila diketahui dengan pasti bahwa mempertahankan kehamilan setelah ditiupkannya ruh akan mengakibatkan meninggalnya ibu, maka kaidah umum syari'at memerintahkan untuk mengambil resiko yang paling ringan, maka tidak ada jalan lain kecuali dengan melakukan tindakan aborsi, karena ibu adalah kehidupan yang telah nyata dan mempunyai garis kehidupan dan sudah mempunyai hak dan kewajiban. ${ }^{39}$ Aborsi setelah ditiupkan ruh yang sengaja dilakukan bukan dalam keadaan darurat untuk menyelamatkan nyawa ibu merupakan kejahatan terhadap nyawa, dalam hukum Islam menurut para fuqaha pelakunya wajib dikenakan sanksi yaitu membayar diyat jika janin keluar dalam keadaan hidup lalu kemudian mati, atau membayar Ghurrah ${ }^{40}$ jika janin keluar dalam keadaan mati. Dasar mengenai ghurrah ini terdapat dalam hadits sebagai berikut:

“Dua orang perempuan dari kabilah Hudzail saling melempar satu terhadap yang lain, kemudian salah satunya menggugurkan janin lain. Berkenaan dengan kejadian ini Rasulullah Saw, memutuskan diyat seorang ghurrah, laki-laki atau perempuan" (Hadits riwayat Bukhari dan Muslim) ${ }^{41}$

Menurut jumhur fuqaha ghurrah yang wajib dibayar karena membunuh janin mempunyai harga terbatas yaitu separuh dari sepersepuluh diyat ibunya ${ }^{42}$, jadi ghurrah nilainya sama dengan lima ekor unta, karena

39 Yusuf Qordhowi dkk, Ensiklopedi Muslimah Modern, (Jakarta: Pustaka Iman, 2009), h.304

40 Gurrah adalah membayar budak laki laki atau perempuan atau yang dapat menggantikannya, gurrah budak tersebut berlaku pada zaman dahulu ketika masih terdapat praktik perbudakan

${ }^{41}$ Al-Faqih Abul Wahid Muhammad bin Muhammad Ibnu Rusyd, Bidayatul Mujtahid Analisa Fiqih Para Mujtahid, (Jakarta: PUSTAKA AMANI, 1989), h. 555.

${ }^{42}$ Al-Faqih Abul Wahid Muhammad bin Muhammad Ibnu Rusyd, Bidayatul Mujtahid Analisa Fiqih Para Mujtahid, (Jakarta: PUSTAKA AMANI, 1989), h. 558 
praktik perbudakan sudah tidak dijumpai lagi pada kehidupan zaman sekarang, maka hukuman bagi pelaku yang tadinya dikenakan membayar gurrah budak dapat diganti seharga lima ekor unta. ${ }^{43}$ Ghurrah menurut arti asalnya adalah khiyar (pilihan), hamba sahaya disebut ghurrah karena merupakan harta pilihan. Dalam prakteknya ghurrah ini dinilai dengan lima ekor unta, atau yang sebanding dengan itu, yaitu lima puluh dinar, atau lima ratus dirham, atau enam ratus dirham. ${ }^{44}$

Dalam tindak pidana atas janin yang dilakukan dengan sengaja menurut ulama malikiyah diyat ghurrahnya diperberat (mughalladzah $)^{45}$, dan untuk tindak pidana atas janin yang menyerupai sengaja ghurrah dapat diringankan (mukhaffafah). ${ }^{46}$

Pandangan Ulama terhadap Sanksi Tindak Pidana Aborsi dalam Fiqh Jinayah, sanksi yang diberlakukan kepada pelaku aborsi dibedakan mejadi lima kategori, tergantung kondisi janin dan waktu dikeluarkannya.

b. Janin pada saat keluar sudah dalam keadaan meninggal

Ketika janin keluar dan terpisah dengan badan ibunya sudah dalam keadaan meninggal, pelaku di kenai sanksi hukuman diyat janin, yaitu gurrah, dengan cara memerdekakan seorang laki-laki atau perempuan budak yang harganya senilai dengan lima ekor unta.

c. Janin korban aborsi tersebut pada awalnya hidup kemudian sengaja dibunuh oleh pelaku.

Dalam kondisi demikian, menurut sebagian pendapat ulama, pelaku yang sadis tersebut harus di kenakan sanksi pidana qishas atau setidaknya diyat secara sempurna. Sanksi hukuman dalam kasus ini sangat berat karena pelaku dinilai sengaja dan merencanakan secara rapi. Jika kepala janin sudah keluar, sedangkan badannya masih berada dalam rahim ibunya dan sudah meninggal menurut ulama kalangan Hanafiyah, Syafi'iyahdan Hadawiyah tetap harus membayar gurrah.

${ }^{43}$ Huzaemah Tahido Yanggo, Fikih Perempuan Kontemporer, (Jakarta: Ghalia Indonesia, 2010), h. 31-32.

${ }^{44}$ Ahmad Wardi Muslich, Hukum Pidana Islam, Jakarta: Sinar Grafika, 2005, h. 225

${ }^{45}$ Mughalladzah maksudnya diyat ghurrahnya diperberat dengan cara harus dibayar dari hartanya sendiri oleh pelaku dengan tunai.

${ }^{46}$ Mukhaffafah maksudnya diyat ghurrah diperingan yaitu bisa dibayar oleh aqilah (keluarga) atau bersama-sama dengan pelaku, lihat Ahmad Wardi Muslich, h. 225. 
d. Pada awalnya janin tersebut hidup kemudian meninggal bukan karena di bunuh pelaku, tetapi karena sebab-sebab lain

Dalam kasus aborsi semacam ini, di mana janin yang awalnya hidup tetapi kemudian karena ibu enggan menyusuinya, si ibu di beri hukuman takzir.

e. Janin bisa keluar dari perut ibunya atau keluar setelah ibunya meninggal

Jika janin baru bisa keluar setelah sang ibu meninggal atau ibunya meninggal dan bayi masih berada dalam perutnya, pelaku aborsi dikenakan hukuman takzir, dengan catatan tidak ada bukti yang menyatakan bahwa pelaku melakukan tindakan-tindakan tertentu untuk menghabisi janin yang masih hidup.

f. Pelaku menganiaya si ibu terlebih dahulu sehingga janin keluar dalam keadaan meninggal

Pelaku bertanggung jawab atas tindakan menganiaya si ibu dan dituntut atas meninggalnya janin. Kalau ada seseorang memberikan makanan atau minuman khusus kepada ibu hamil lalu ibu hamil itu mengkonsumsinya dan berakibat pada kematiannya setelah terlebih dahulu janinnya dikeluarkan juga dalam keadaan meninggal, orang tersebut di tuntut pidana atas pembunuhan si ibu dengan kategori pembunuhan syibhu' amdin (menyerupai sengaja) dan ia harus membayar gurrah atas kematian janin. Jadi pelaku bertanggung jawab atas jarimah pembunuhan dan aborsi. ${ }^{47}$

\section{Fakta-fakta aborsi}

Praktik aborsi akhir-akhir ini menunjukkan fenomena yang semakin marak dengan jumlah angka yang cukup mengagetkan. Untuk lingkup secara makro dapat dilihat dari berbagai sumber data yang akan penulis sajikan sebagai berikut:

Laporan WHO memperlihatkan dalam hitungan satu tahun angka aborsi mencapai sekitar 4,2 juta kasus untuk wilayah Asia Tenggara. Di Indonesia sendiri menempati angka 750.000 hingga 1.500 .000 kasus yang terjadi atau

\footnotetext{
${ }^{47}$ M. Nurul Irfan, Gratifikasi dan Kriminalitas Seksual dalam Hukum Pidana Islam, (Jakarta : AMZAH, 2014), cetakan pertama, h. 99-101
} 
dapat dikatakan 50 persennya terjadi di Indonesia, dengan jumlah sekitar 2.500 aborsi yang mengakibatkan kematian. ${ }^{48}$

Konteks aborsi tidak aman yang dapat menimbulkan tingginya angka kematian ibu, bukan merupakan persoalan yang sederhana, tetapi memiliki dimensi sosial yang kompleks baik secara fisik, psikis bagi uang bersangkutan maupun psikososial bagi lingkungannya, fikih dalam hal ini harus berorientasi pada etika sosial yang produk hukumnya tidak sekedar halal atau haram, boleh atau tidak, tetapi harus memberi jawaban berupa solusi hukum terhadap persoalan-persoalan sosial yang dihadapi perempuan. ${ }^{49}$

Aborsi merupakan masalah kesehatan masyarakat karena memberikan dampak pada kesakitan dan kematian ibu. Di Indonesia, data statistik tentang penyebab utama kematian ibu hamil dan melahirkan yang sering disebarluaskan adalah: pendarahan, infeksi dan eklampsia. Namun sebenarnya aborsi juga merupakan kematian ibu, hanya saja dalam rekam medis biasanya aborsi dimasukan dalam ibu yang disebabkan komplikasi aborsi seringkali tidak muncul dalam laporan kematian, tetapi dilaporkan sebagai pendarahan atas sepsis. Hal itu terjadi karena hingga saat ini aborsi masih merupakan masalah kontroversial di masyarakat. Di satu sisi aborsi dianggap ilegal dan dilarang oleh agama sehingga masyarakat cenderung menyembunyikan kejadian aborsi, di lain pihak aborsi tetap saja terjadi di masyarakat. Terlepas dari semua penyebab kehamilan, memang fenomena kehamilan yang tidak dikehendaki (KTD) selalu ada sepanjang kehidupan manusia. ${ }^{50}$

Konferensi Internasional Kependudukan dan Pembangunan (ICPD) di Kairo Tahun 1994 dan Konferensi Wanita di Beijing tahun 1995 menyepakati bahwa akses pada pelayanan aborsi yang aman merupakan bagian dari hak wanita untuk hidup, hak wanita untuk menerima standar pelayanan kesehatan dan informasi. Dengan demikian, diperlukan perlindungan hukum dalam menyelenggarakan pelayanan aborsi yang aman untuk menjamin hak wanita dalam menentukan fungsi reproduksi dan peran reproduksi tubuhnya sendiri. Penyebab utamanya terletak pada efektifitas pelayanan konseling

48 Maria Ulfa Anshor, Fikih Aborsi (Wacana Penguatan Hak Reproduksi Perempuan). (Jakarta: Buku Kompas, 2006), Cetakan pertama, h. 42

${ }^{49}$ Sahal Mahfudh, Figh Sosial; Upaya Pengembangan Mazhab Qouli dan Mazhab Manhaji, (Jakarta: UIN, 2003), h. 18

${ }^{50}$ Maria Ulfa Anshor, dkk, (Aborsi Dalam Perspektif Figh Kontemporer), (Jakarta : Balai Penerbit Fakultas Kedokteran Indonesia, 2002), h. 176 
pasca aborsi yang mewajibkan pemakaian kontrasepsi bagi mereka yang masih seksual aktif namun tidak ingin mempunyai anak dalam jangka waktu tertentu. Selain itu dalam konseling diajarkan juga cara-cara berkomunikasi dengan pasangan agar sama-sama mencegah terjadinya kehamilan. ${ }^{51}$

Hamil di luar nikah atau kehamilan yang tidak diinginkan baik buah dari hubungan yang disengaja (suka sama suka) maupun akibat perkosaan selalu menorehkan kegetiran luar biasa. Perasaan gelisah, takut, panik dan sesal berkepanjangan menyita hampir seluruh waktu hidupnya. Jika salah satu pihak (pria maupun wanita atau kedua-duanya) dalam kondisi tidak siap, maka kehamilan menjadi suatu malapetaka. Kisah-kisah kehamilan tak diinginkan ini sungguh bejibun. Ada yang karena ditinggal kabur kekasihnya, atau sang Arjuna yang tidak bisa bertanggung jawab karena sudah berkeluarga. Masalah juga bisa datang dari pihak wanita yang gamang karena harus mengarungi bahtera rumah tangga bersama kekasihnya yang tak punya masa depan, belum cukup umur, belum selesai kuliah dan lain-lain. Contohcontoh di atas hanyalah sebagian kecil problematika kehamilan di luar nikah akibat perbuatan terkutuk yang dilakukan atas dasar suka sama suka. Meskipun demikian, tetap membawa malapetaka besar bagi si wanita. Selain harus menanggung malu terhadap lingkungannya, was-was menanti tanggung jawab si pria, dan was-was menatap masa depan menyangkut dirinya sendiri dan jabang bayi. Lalu bagaimana jika kehamilan itu akibat dari perbuatan semena-mena alias perkosaan? Bisa dibayangkan betapa remuk redamnya pihak wanita dan keluarganya. Sakit luar biasa lahir maupun batin. Belum lagi gangguan tak enak dari dalam tubuh pada masa kehamilan. Problemnya meliputi fisik dan non fisik. Bisa jadi perasaan sesaat bahkan seumur hidup, si wanita akan membenci janin yang ada dalam perutnya karena dihantui perasaan jijik atas perbuatan bapaknya. Kalau sudah demikian lantas bagaimana bisa mengasuh dan mendidik anaknya kelak dengan baik? Kehamilan akibat perkosaan tidak selamanya bisa diselesaikan dengan pernikahan sebagai bentuk pertanggung jawaban si pelaku pemerkosaan. Harus dipahami bila ada beberapa wanita memilih menolak dinikahi oleh pria pemerkosanya meski si pria menyesal perbuatannya dengan penuh rasa tanggung menikahinya tapi dia memilih menjadi single parent. Tentunya setelah melalui berbagai pertimbangan yang matang. Korban dan keluarganya mempunyai trauma yang cukup berat, tidak bisa

${ }^{51}$ Maria Ulfa Anshor, dkk, (Aborsi Dalam Perspektif Fiqh Kontemporer), (Jakarta : Balai Penerbit Fakultas Kedokteran Indonesia, 2002), h. 177 
menghilangkan perasaan jijik, dan terlanjur mencap pelaku sebagai penjahat. Bagaimana mungkin menikah dengan orang yang sangat dibenci karena perbuatan kejam yang telah memporak-porandakan masa depan dan kehormatannya? Bagaimana bisa ia menjadi figure teladan bagi anaknya kelak? Lagipula ia (wanita korban perkosaan) merasa tidak punya alasan mengapa harus menikah dengan pelaku. Seandainya ia niatkan menikah demi status anaknya kelak pun tak ada pengaruhnya apa-apa. ${ }^{52}$

Sementara itu, untuk faktor yang menjadi latar belakang dari dilakukannya aborsi menyebutkan bahwa alasan mengapa melakukan aborsi, sebagian besar 41,2 persen karena jumlah anak sudah cukup. 16,1 persen karena anak terakhir masih kecil, dan belum siap punya anak 10,2 persen. ${ }^{53}$ Tetapi, menurut Nunik Widyantoro 58 persen karena alasan psikososial dan 36 persen karena gagal KB, 4 persen karena indikasi kesehatan, 0,1 persen karena kekerasan, 2 persen sebab lainnya. ${ }^{54}$ Dengan penyebab latar belakang kehamilan bermacam-macam, antara lain disebabkan ada yang normal karena dilakukan suka sama suka, tetapi tidak menggunakan alat kontrasepsi, atau menggunakan alat kontrasepsi gagal, ada yang karena terpaksa melakukan hubungan seksual dibawah ancaman, hamil karena pemerkosaan baik karena orang dekat yang memiliki hubungan darah (incest) maupun orang lain yang sama sekali tidak mempunyai hubungan kekerabatan apapun. ${ }^{55}$

Pengakhiran kehamilan (aborsi) memang tidak selalu aman. Di negara-negara yang pengakhiran kehamilannya belum legal, banyak perempuan mati atau mendapat masalah kedokteran yang serius setelah berusaha melakukan pengakhiran kehamilannya sendiri, atau pergi ke dukun (yang tidak terlatih) yang memakai alat-alat primitif atau tidak bersih. Akhirnya perempuan-perempuan itu akan memenuhi Unit Gawat Darurat (UGD) dengan komplikasi yang sangat serius, seperti tembusnya peranakan, sisa-sisa plasenta yang tertinggal, pendarahan banyak, robekan mulut rahim, infeksi hebat, keracunan, shock dan membusuk. Di selurh dunia, di negara-

52 Fakta aborsi http://www.kompasiana.com/icha nors/bila-terlanjur-hamil-karenadiperkosa diakses tanggal 12 februari 2016

53 Maria Ulfa Anshor, Fikih Aborsi (Wacana Penguatan Hak Reproduksi Perempuan). (Jakarta: Buku Kompas, 2006), Cetakan pertama, h. 45

${ }_{54}$ Nunik Widyantoro,( Pengakhiran Kehamilan Tak Diinginkan yang Aman Berbasis Konseling ), (Jakarta: Yayasan Kesehatan Perempuan, 2003), h. 3

${ }_{55}$ Maria Ulfa Anshor, Fikih Aborsi (Wacana Penguatan Hak Reproduksi Perempuan). (Jakarta: Buku Kompas, 2006), Cetakan pertama, h. 46 
negara dimana pengakhiran kehamilan masih ilegal, pengakhiran kehamilan merupakan penyebab utama kematian ibu. ${ }^{56}$

Di negara-negara yang pengakhiran kehamilan (aborsi) sudah legal, para perempuannya lebih beruntung karena dapat memanfaatkan kemajuan teknologi kedokteran yang lebih aman. Waktu yang paling aman untuk melakukan aborsi adalah antara 6-10 minggu dari hari pertama haid terakhir. Jarang sekali terjadi komplikasi yang serius kalau dilakukan sebelum 12 minggu. Biasanya 89\% perempuan melakukan aborsi pada kehamilan kurang dari 12 minggu. Dari perempuan-perempuan ini, 97\% tidak melaporkan terjadinya komplikasi 2,5\% mengalami komplikasi ringan yang dapat diatasi di praktek dokter atau di klinik pengakhiran kehamilan (aborsi), dan kurang dari $0,5 \%$ memerlukan tindakan medis atau perawatan di rumah sakit. ${ }^{57}$

Salah satu contoh kongkret dari slippery slope $e^{58}$ ini adalah hubungan erat antara antara kontrasepsi dengan aborsi. Para superter kontrasepsi selalu berargumen, bahwa dengan tersedianya alat kontrasepsi yang terjangkau bagi semua orang, akan mengurangi secara drastis masalah aborsi dan kehamilan remaja. Secara teoritis pandangan ini mungkin bisa benar dan masuk akal, sebab kalau alat kontrasepsi tersedia, maka orang akan memakai alat kontrasepsi ketika mereka berhubungan sex. Oleh karena memakai alat kontrasepsi, maka tidak akan ada kehamilan. Kalau tidak ada kehamilan maka tidak ada aborsi. Jalan pikiran macam ini kelihatan logis dan runtun, tidak ada sesuatu yang patut untuk di pertanyakan. Akan tetapi, dalam praktek tidaklah demikian. Dalam cara pandang itu diperhitungkan tingkat kegagalan pencegahan kehamilan yang prosentasenya cukup besar, baik dikalangan ibu yang bersuami maupun dikalangan remaja. Kegagalan itu bisa disebabkan berbagai faktor, misalnya lupa meminum pil, kondom yang bocor, tidak tapat mempergunakan alat kontrasepsi, kualitas yang buruk alat

\footnotetext{
${ }_{56}$ Maria Ulfa Anshor, dkk, (Aborsi Dalam Perspektif Figh Kontemporer), (Jakarta : Balai Penerbit Fakultas Kedokteran Indonesia, 2002), h. 15

${ }^{57}$ Maria Ulfa Anshor, dkk, (Aborsi Dalam Perspektif Figh Kontemporer), (Jakarta : Balai Penerbit Fakultas Kedokteran Indonesia, 2002), h. 16

58 Secara harfiah berarti: lereng yang curam dan licin. Kalau kita berjalan turun pada lereng yang curam dan licin, sekali kita melangkah ke bawah, kita akan sulit untuk berhenti, karena badan kita sendiri condong ke depan, sedangkan di depan kita tidak ada penyangga, padahal jalannya licin, sehingga mudah terpeleset dan jatuh, atau lihat pengertian selengkapnya di CB. Kusmaryanto, Kontroversi Aborsi, (Jakarta: PT. Grasindo, Anggota IKAPI, 2002), Cetakan pertama, h. 179
} 
kontrasepsi dan lain-lainnya. Jumlah yang gagal ini bukan prosentasi yang sedikit dimasyarakat kita. ${ }^{59}$

\section{Aborsi Pemerkosaan Dan Keadaan Darurat}

Perkosaan berasal dari kata dasar "Perkosa" yang berarti dipaksa, gagah, kuat, perkasa. Memperkosa berarti menundukkan dengan kekerasan, memaksa, melanggar dengan kekerasan. Sedangkan pemerkosaan diartikan sebagai proses cara perbuatan memperkosa dengan kekerasan. Dengan demikian perkosaan memiliki unsur-unsur pria memaksa dengan kekerasan, bersetubuh dengan seorang wanita atau perbuatan persetubuhan dengan seorang wanita yang bukan istrinya dengan cara paksaan. ${ }^{60}$

Perkosa, memperkosa dalam buku Supriyadi Widodo Eddyono yang berjudul Kejahatan Perkosaan Dalam RUU KUHP berarti: (1) mengambil, memiliki punya orang dengan paksa, dan dengan kekuatan atau kekuasaan; (2) mengagagahi, menyebadani seorang wanita dengan paksa dan kekerasan; (3) melanggar, dengan sengaja tak mau mematuhi. ${ }^{61}$

Pemerkosaan dalam KUHP hukumnya diatur dalam pasal 284 dan pasal 285 Kitab Undang-Undang Hukum Pidana Indonesia disebutkan :

Diancam dengan pidana penjara paling lama sembilan bulan:

> laki-laki yang telah kawin yang melakukan mukah (overspel), padahal diketahui bahwa 27 BW berlaku baginya.

> Seorang perempuan yang telah kawin yang telah melakukan mukah.

> Seorang laki-laki yang turut serta melakukan perbuatan itu, padahal diketahuinya bahwa yang turut bersalah telah kawin.

$>$ Seorang perempuan yang tidak kawin yang turut serta melakukan perbuatan itu, padahal diketahui olehnya bahwa yang turut bersalah telah kawain dan pada pasal $27 \mathrm{BW}$ berlaku baginya. ${ }^{62}$

${ }^{59}$ CB. Kusmaryanto, Kontroversi Aborsi, (Jakarta: PT. Grasindo, Anggota IKAPI, 2002), Cetakan pertama, 180

${ }^{60}$ Tim Penyusunan Kamus Pusat Pengembangan dan Pembinaan Bahasa, Kamus Besar Bahasa Indonesia, (Jakarta: PT. Gramedia Pustaka Utama, 1990), h. 1059

${ }^{61}$ Supriyadi Widodo Eddyono, dkk, (Kejahatan Perkosaan Dalam RUU KUHP), (Jakarta: Elsam Dan Tifa, 2007),cetakan pertama. h. 7

${ }^{62}$ Andi Hamzah, KUHP DAN KUHAP, (Jakarta ; Rineka Cipta, 2010), h. 114 
Selain menyatakan dengan tegas tentang kejahatan perkosaan dalam KUHP, yakni di pasal 285, KUHP juga mengatur mengenai kejahatan persetubuhan lainnya, walaupun tidak secara tegas dinyatakan sebagai sebuah kejahatan perkosaan, bahkan dianggap bukan delik perkosaan. Kejahatan-kejahatan dalam lingkup persetubuhan tersebut ialah: (1) Persetubuhan diluar kawin dengan wanita yang tidak berdaya; (2) Persetubuhan dengan wanita yang belum cukup umur, dan (3) Persetubuhan dengan istri yang belum waktunya untuk dikawin. ${ }^{63}$

Sementara pengertian pemerkosaan dalam Qanun Hukum Jinayat Aceh, tidak terbatas pada kaum perempuan saja, tetapi korban perkosaan dapat mencakup laki-laki. Hal itu dapat dilihat dari pengertian "pemerkosaan" dalam pasal 1 angka 24 QHJA. ${ }^{64}$

"Pemerkosaan" adalah hubungan seksual terhadap faraj atau dubur korban dengan zakar pelaku atau benda lainnya yang digunakan pelaku atau terhadap faraj atau zakar korban dengan mulut pelaku atau terhadap mulut korban dengan zakar pelaku, dengan kekerasan atau paksaan atau ancaman terhadap korban, tidak termasuk hubungan seksual yang dilakukan oleh suami atau istri"

\section{Pemerkosaan Menurut Hukum Islam}

Dalam hukum Islam perkosaan sebagaimana yang penulis kutip dalam kitabnya At Tasyri' al-Jinaiy al-Islamiy, pemerkosaan adalah perbuatan yang diancam hukuman hadd karena perbuatan tersebut dilakukan dengan adanya unsur paksaan atau keterpaksaan dari salah satu pihak sebagai korban dapat diartikan sebagai perbuatan zina. ${ }^{65}$

Dalam buku Fikih Jinayah Upaya Menanggulangi Kejahatan dalam Islam A. Djazui bahwa konsep tentang perzinaan menurut hukum Islam jauh berbeda dengan sistem hukum Barat, karena dalam hukum Islam, setiap hubungan seksual yang diharamkan itulah zina, baik yang dilakukan oleh orang yang berkeluarga ataupun yang belum asalkan orang tersebut telah

${ }^{63}$ Supriyadi Widodo Eddyono, dkk, ( Kejahatan Perkosaan dalam RUU KUHP ), (Jakarta: Elsam Dan Tifa, 2007), cetakan pertama, h. 45

64 Neng Djubaedah, ( Perzinaan Dalam Peraturan Perundang-undangan di Indonesia ditinjau dari Hukum Islam), (Jakarta: Kencana Prenada Media Group, 2010), Cetakan ke-1, h. 112

${ }^{65}$ Tim Salsilah, Ensiklopedia Hukum Pidana Islam IV, (PT. Kharisma Ilmu), ( At-Tasyri' alJinaiy al-Islamiy Muqaranan bil Qanunil Wad'iy, Bab XIX, Zina,2006 ), h. 164 
mukallaf, meskipun dilakukan suka sama suka tetap merupakan suatu tindak pidana. ${ }^{66}$

Pemerkosaan dalam Islam memang tidak diatur secara jelas dalam AlQur'an, namun para ulama sepakat bahwa pelaku pemerkosaan dikenakan hukuman hadd dan tidak ada hukuman had bagi wanita yang diperkosa, karena hal ini adalah zina dengan pemaksaan, sementara pengertian paksaan adalah membawa kepada sesuatu yang tidak disukainya secara paksa. ${ }^{67}$ Dimana keadaan tersebut dapat digolongkan kepada keadaan darurat, yaitu seorang wanita yang menjadi korban dipaksa untuk melakukan persetubuhan yang dilarang. Dengan demikian korban tidak dikenai hukuman atau dengan kata lain terlepas dari pertanggungjawaban pidana. ${ }^{68}$ Pendapat di atas di dasarkan pada firman Allah SWT: (QS. An-Nahl [16] : 106)

"Barangsiapa yang kafir kepada Allah sesudah dia beriman (dia mendapat kemurkaan Allah), kecuali orang yang dipaksa kafir padahal hatinya tetap tenang dalam beriman (dia tidak berdosa), akan tetapi orang yang melapangkan dadanya untuk kekafiran, maka kemurkaan Allah menimpanya dan baginya azab yang besar". (QS. An-Nahl [16] : 106)

Sedangkan perkosaan sama halnya dengan pemaksaan. Terpaksa adalah kondisi dimana seseorang melakukan perbuatan karena tekanan orang lain sehingga hilang kerelaannya atau rusak kehendaknya. Sebagian ahli berpendapat, bahwa batasan terpaksa adalah kondisi dimana seseorang merasa ditekan oleh orang lain yang mampu memaksanya melalui bermacam siksaan yang mempengaruhi orang berakal untuk berbuat apa yang dipaksakan padanya dan hal itu mendominasi dugaan bahwa orang yang memaksa akan melakukan apa yang dipaksakan jika ia tidak mau melakukan apa yang dipaksakan. ${ }^{69}$

Dalam hukum Islam, terpaksa ada dua macam. Pertama, terpaksa yang menghilangkan kerelaan dan merusak kehendak, yaitu sesuatu yang dikhawatirkan akan menghilangkan jiwa. Ini disebut pemaksaan sempurna

${ }^{66}$ A. Djazuli, Figh Jinayah Upaya Menanggulangi Kejahatan Dalam Islam, (Jakarta: Raja Grafindo Persada, 1997), h. 35

${ }_{67}$ Wahbah Zuhaili, al-Fighu al-Islami wa adillatuhu, (Damaskus, Daaral-Fikr, 1984), Juz V, h. 386

68 A. Hanafie, Ushul Figh, ( Jakarta: Widjaya, 1962), Cetakan Ke-3, h. 56.

69 Tim Salsilah, Ensiklopedia Hukum Pidana Islam II, ( At-Tasyri' al-Jinaiy al-Islamiy Muqaranan bil Qanunil Wad'iy, Bab Zina ) (Jakarta: PT. Kharisma Ilmu, diterjemahkan oleh Tim Salsilah, 2006), h. 176 
atau terpaksa. Kedua, pemaksaan yang menghilangkan kerelaan atau merusaknya, tetapi tidak rusak kehendak, yaitu pemaksaan yang secara kebiasaan tidak dikhawatirkan dapat menghilangkan jiwa, seperti menahan, mengikat, memukul yang tidak dikhawatirkan akan membinasakan. pemaksaan ini disebut dengan pemaksaan yang kurang atau tidak mendesak. Pemaksaan sempurna memengaruhi kerelaan dan kehendak, seperti melakukan tindak pidana. Pemaksaan terhadap seseorang yang melakukan tindak pidana pembunuhan misalnya, membuat pemaksaan tersebut menghilangkan rida dan dan merusak kehendaknya. ${ }^{70}$

\section{Syarat-syarat pemaksaan ${ }^{71}$}

Syarat-syarat pemaksaan sebagaimana di sebutkan oleh Abdul Qadir Audah dalam Ensiklopedia Hukum Pidana Islam terdiri dari dua yaitu Pertama, ancaman harus berupa sesuatu yang membahayakan, yang sekiranya bisa menghilangkan kerelaan atau merusaknya, seperti, memukul, menahan, mengikat, dan tidak memberi makan. Jika ancaman tidak berpengaruh terhadap kerelaan, pemaksaan dianggap tidak ada. Memastikan ancaman sebagai sesuatu yang berbahaya. Kedua, ancaman harus berupa perintah seketika yang dikhawatirkan bakal terjadi jika orang yang dipaksa tidak melakukan perintah itu. Jika ancaman bukan perintah seketika, itu bukan dianggap pemaksaan karena orang yang dipaksa masih mempunyai waktu untuk melindungi dirinya sehingga ia bisa mengadu kepada pemimpin negara atau lari dari orang yang memaksa. Untuk mengukur ancaman termasuk seketika atau tidak, dikembalikan pada kondisi orang yang dipaksa dan dugaan kuat yang didasarkan pada sebab-sebab akal. Ancaman dianggap seketika ketika orang yang dipaksa tidak mampu menghindar, melawan, meminta tolong orang lain, atau bermacam-macam bentuk pembelaan diri.

Sedangkan secara hukumannya para ulama sepakat tidak ada hukuman hudud atas orang yang dipaksa berzina. ${ }^{72}$ Allah SWT berfirman, (Q.S al-An'am [6]: 119).

70 Tim Salsilah, Ensiklopedia Hukum Pidana Islam II, ( At-Tasyri' al-Jinaiy al-Islamiy Muqaranan bil Qanunil Wad'iy, Bab Zina ), (Jakarta: PT. Kharisma Ilmu, diterjemahkan oleh Tim Salsilah, 2006), h.177

71 Tim Salsilah, Ensiklopedia Hukum Pidana Islam II, ( At-Tasyri' al-Jinaiy al-Islamiy Muqaranan bil Qanunil Wad'iy, Bab Zina ), (Jakarta: PT. Kharisma Ilmu, diterjemahkan oleh Tim Salsilah, 2006), h.179 
“.... Padahal sesungguhnya Allah telah menjelaskan kepada kamu apa yang diharamkan-Nya atasmu, kecuali jika kamu dalam keadaan terpaksa ....." (QS. al-An'am [6]: 119)

“ .... Tetapi barangsiapa dalam keadaan terpaksa (memakannya) sedang dia tidak menginginkannya dan tidak (pula) melampaui batas, maka tidak ada dosa baginya ....."(QS. Al-Baqarah [2]: 173)

Sejak awal perlu dicatat bahwa meskipun perkosaan sendiri adalah kejahatan seksual, perkosaan sama sekali tidak sama dengan perzinaan dan pergaulan seks bebas, karena perkosaan melibatkan pemaksaan dan kekerasan. ${ }^{73}$

\section{Pengertian dan Dasar Hukum Islam Keadaan Darurat}

Al-dlarurah diambil dari akar kata الاضطر ار yang artinya, kebutuhan mendesak. ${ }^{74}$ Dlarurat berasal dari kata darra, yadurru, dan darran $=$ merusak atau memberi mudarat. Keadaan yang sangat merusak atau sangat memaksa; kebutuhan yang amat mendesak dan amat berbahaya apabila tidak terpenuhi. ${ }^{75}$ Al-Dlarurah secara istilah bisa diartikan, "Halangan yang menyebabkan seseorang boleh melakukan sesuatu yang dilarang".

Dasar yang dijadikan referensi kaidah ini adalah firman Allah surat Al-An'am, ayat 119 (QS. Al-An'am [ 6 ] : 119)

"Padahal sesungguhnya Allah telah menjelaskan kepada kamu apa yang diharamkan-Nya atasmu, kecuali apa yang terpaksa kamu memakannya". (QS. Al-An'am [ 6 ] : 119)

Jadi darurat adalah suatu keadaan di mana sesorang apabila tidak melakukan sesuatu yang diharamkan maka ia akan mati. ${ }^{76}$ Dalam terminologi

72 Tim Salsilah, Ensiklopedia Hukum Pidana Islam II, ( At-Tasyri' al-Jinaiy al-Islamiy Muqaranan bil Qanunil Wad'iy, Bab XIX Zina ), (Jakarta: PT. Kharisma Ilmu, 2006), h. 164

73 Abul Fadl Mohsin Ebrahim, Aborsi Kontrasepsi dan Mengatasi Kemandulan (Isu-isu Biomedis Dalam Perspektif Islam. (Bandung : Penerbit Mizan Anggota IKAPI, 1997), h. 146

${ }^{74}$ Muhammad Sidqi Bin Ahmad Al-Burniu, Al-Waziz Fi Idah Qawaidul Fighi Al-Quliah, (Riat: Muasasah Ar-Risalah), h. 143-144. Lihat lebih lanjut Ahmad Sudirman Abbas, Qawaid Fighiyyah dalam Perspektif Fiqh, (Jakarta: Pedoman Ilmu Jaya, 2004), cetakan pertama, h. 109

${ }^{75}$ Hafiz Dasuki, Ensiklopedi Hukum Islam, (Jakarta: PT Ichtiar Baru Van Hoeve, 1997), Cetakan pertama, h. 260

${ }^{76}$ Muhammad Sidqi Bin Ahmad Al-Burniu, Al-Waziz Fi Idah Qawaidul Fighi Al-Quliah, (Riat: Muasasah Ar-Risalah), h. 149 
yang lain keadaan darurat dalam istilah agama Islam diartikan sebagai suatu keadaan yang memungkinkan umat Islam tidak menaati Syari'at Islam, ialah keadaan yang terpaksa atau dalam keadaan yang membahayakan diri secara lahir dan bathin, dan keadaan tersebut tidak diduga sebelumnya atau tidak diinginkan sebelumnya, demikian pula dalam memanfaatkan keadaan tersebut tidak berlebihan. Jika keadaan darurat itu berakhir maka segera kembali kepada ketentuan syari'at yang berlaku. ${ }^{77}$

Darurah dan ikrah mempunyai pengertian yang sama, yaitu suatu keterpaksaan yang dibolehkan untuk melakukan sesuatu perbuatan yang dilarang. Tetapi dalam kenyataannya, kedua bentuk keterpaksaan itu berbeda. Keterpaksaan dalam bentuk darurat adalah keterpaksaan yang timbul secara alami tanpa ada keterlibatan manusia seperti sakit keras, kelaparan, kehausan, dan lain-lain. Sedangkan ikrah adalah keterpaksaan yang timbul dengan adanya keterlibatan manusia seperti yang diancam dengan sengaja untuk mengucapkan kalimat kufur. ${ }^{78}$

\section{Dasar hukum Keadaan Darurat}

Dasar hukum Islam terhadap keadaan darurat sama seperti dalam paksaan. Dalam keadaan tidak dihapuskannya hukuman atas tindak pidana, ia tetap mendapatkan hukuman karena tidak adanya ilja' (keadaan darurat yang menyangkut keselamatan nyawa). Dalam keadaan pembolehan (ibahah), perbuatan dibolehkan karena tidak ada alasan yang mengharamkan. Dalam keadaan penghapusan hukuman, hukuman dihapuskan karena adanya ilja' dan tidak adanya ikhtiar. ${ }^{79}$

Dasar hukum dari darurat bersumber dari Alquran. Dalam Alquran dijelaskan apabila seseorang dalam keadaan yang terpaksa tanpa sengaja dan tidak melampaui batas, maka ia tidak berdosa (QS. Al-Baqarah [2]; 173, QS. Al-An'am [6]; 145 dan QS.An- Nahl [16]; 115

"Sesungguhnya Allah hanya mengharamkan bagimu bangkai, darah, daging babi, dan binatang yang (ketika disembelih) disebut (nama) selain Allah. Tetapi barangsiapa dalam keadaan terpaksa (memakannya) sedang dia tidak

77 http:id.wikipedia.org/wiki/syariat_Islam, diakses pada tanggal 28 februari 2016

${ }^{78}$ Hafiz Dasuki, Ensiklopedi Hukum Islam, (Jakarta: PT Ichtiar Baru Van Hoeve, 1997), Cetakan pertama, h. 260

${ }^{79}$ Abdul Qadir Audah, Ensiklopedia Hukum Pidana Islam II, (PT. Kharisma Ilmu), ( AtTasyri' al-Jinaiy al-Islamiy Muqaranan bil Qanunil Wad'iy, 2006 ), h. 239 
menginginkannya dan tidak (pula) melampaui batas, maka tidak ada dosa baginya. Sesungguhnya Allah Maha Pengampun lagi Maha Penyayang". (QS. Al-Baqarah [2]; 173)

Katakanlah: "Tiadalah aku peroleh dalam wahyu yang diwahyukan kepadaku, sesuatu yang diharamkan bagi orang yang hendak memakannya, kecuali kalau makanan itu bangkai, atau darah yang mengalir atau daging babi -- karena sesungguhnya semua itu kotor -- atau binatang yang disembelih atas nama selain Allah. Barangsiapa yang dalam keadaan terpaksa, sedang dia tidak menginginkannya dan tidak (pula) melampaui batas, maka sesungguhnya Tuhanmu Maha Pengampun lagi Maha Penyayang". (QS. Al-An'am [6]; 145)

"Sesungguhnya Allah hanya mengharamkan atasmu (memakan) bangkai, darah, daging babi dan apa yang disembelih dengan menyebut nama selain Allah; tetapi barangsiapa yang terpaksa memakannya dengan tidak menganiaya dan tidak pula melampaui batas, maka sesungguhnya Allah Maha Pengampun lagi Maha Penyayang". (QS.An- Nahl [16]; 115)

\section{Pemahaman Agama Terhadap hak-hak Reproduksi}

Dalam pemahaman kebanyakan pemeluk agama, tanggung jawab dan beban terbesar tentang proses reproduksi lebih bertumpu dan dibebankan pada perempuan. Perempuan ditempatkan sebagai objek terutama mengenai elemen-elemen reproduksi, bahkan lebih ironis lagi apabila terjadi kesalahan, maka kesalahan dibebankan kepada perempuan. Padahal, dalam kaitannya dengan hak kesehatan reproduksi Al-Qur'an menekankan prinsip keadilan dan adanya penghormatan terhadap hak-hak tersebut, sebagaimana tertuang dalam (QS. Al-Ahqaf [46]: 15)

“ Kami perintahkan kepada manusia supaya berbuat baik kepada dua orang ibu bapaknya, ibunya mengandungnya dengan susah payah, dan melahirkannya dengan susah payah (pula). Mengandungnya sampai menyapihnya adalah tiga puluh bulan, sehingga apabila dia telah dewasa dan umurnya sampai empat puluh tahun ia berdoa: "Ya Tuhanku, tunjukilah aku untuk mensyukuri nikmat Engkau yang telah Engkau berikan kepadaku dan kepada ibu bapakku dan supaya aku dapat berbuat amal yang saleh yang Engkau ridhai; berilah kebaikan kepadaku dengan (memberi kebaikan) kepada anak cucuku. Sesungguhnya aku bertaubat kepada Engkau dan sesungguhnya aku termasuk orang-orang yang berserah diri".(QS. Al-Ahqaf [46]: 15) 
Dengan adanya persepsi atau pandangan yang menempatkan perempuan sebagai obyek seksualitas dalam satu sisi dan obyek kesalahan disisi yang lainnya terkait dengan persoalan hak-hak reproduksi, termasuk persoalan aborsi perlu dikaji kembali sebagai bahan untuk merumuskan fikih aborsi alternatif bagi penguatan hak reproduksi perempuan. Seperti adanya anggapan bahwa kasus aborsi banyak disebabkan akibat kehamilan diluar nikah. Sehingga memukul rata semua pihak yang melakukan aborsi menjadi berdosa. Dengan mengesampingkan faktor lain yang juga menjadi faktor yang mempunyai mudharat yang sama besarnya. Misalnya orang yang diperkosa lalu hamil, mereka adalah korban. Tetapi, ketika menghadapi persoaln ini, sebagian besar masyarakat tidak ada yang berempati atau memberi solusi dan selalu saja bertindak menghakimi. ${ }^{80}$

Pemahaman agama yang dipersempit oleh tradisi dan budaya patriakhi telah melarang aborsi sehingga memaksa perempuan harus menanggung resiko KTD (Kehamilan yang Tidak Dikehendaki). Adanya pengklaiman yang menganggap aborsi adalah pelanggaran terhadap doktrin agama bahkan dianggap pembunuhan. Mengingat risiko yang ditimbulkannya terhadap kesehatan reproduksi perempuan dan keselamatan jiwa perempuan. Kondisi tersebut secara langsung atau tidak telah mempengaruhi para pengambil keputusan di negeri ini dalam membuat keputusan-keputusan tidak adil yang berkaitan dengan penghentian kehamilan. Ketidakadilan di level negara yang mempengaruhi kebijakan tentang aborsi adalah tidak adanya peraturan pemerintah mengenai UndangUndang Nomor 23/1992 tentang kesehatan, selama lebih dari 12 tahun. ${ }^{81}$

\section{Hak Kesehatan Reproduksi pada Perempuan}

Kesehatan reproduksi merupakan keadaan sehat secara fisik, mental, dan sosial secara utuh, tidak semata-mata bebas dari penyakit atau kecacatan yang berkaitan dengan sistem, fungsi dan proses reproduksi pada laki-laki dan perempuan, khususnya lebih mengutamakan pada kesehatan perempuan karena meliputi; saat sebelum hamil, melahirkan, dan sesudah melahirkan; pengaturan kehamilan, alat kontrasepsi, dan kesehatan seksual; dan

${ }^{80}$ Elga Sarapung, Masrucah, M. Imam Aziz, Agama dan Kesehatan Reproduksi", (Jakarta: Pustaka Sinar Harapan, 1999), Cetakan pertama, h. 162

${ }^{81}$ Elga Sarapung, Masrucah, M. Imam Aziz, Agama dan Kesehatan Reproduksi", (Jakarta: Pustaka Sinar Harapan, 1999), Cetakan pertama, h. 166 
kesehatan sistem reproduksi. Kesehatan, reproduksi dilaksankan melalui kegiatan promotif, preventif, kuratif, dan rehabilitatif. ${ }^{82}$

Setiap orang berhak: menjalani kehidupan reproduksi dan kehidupan seksual yang sehat, aman, serta bebas dari paksaan dan/atau kekerasan dengan pasangan yang sah, menentukan kehidupan reproduksinya dan bebas dari diskriminasi, paksaan dan/atau kekerasan yang menghormati nilai-nilai luhur yang tidak merendahkan martabat manusia sesuai dengan norma agama serta menentukan sendiri kapan dan berapa sering ingin berproduksi sehat secara medis serta tidak bertentangan dengan norma agama. Memperoleh informasi, edukasi, dan konseling mengenai kesehatan reproduksi yang benar dan dapat dipertanggungjawabkan. Pemerintah wajib menjamin ketersediaan sarana informasi dan sarana pelayanan kesehatan reproduksi yang aman, bermutu, dan terjangkau masyarakat, termasuk keluarga berencana. ${ }^{83}$

Dalam QS. Al-Nisa' [4] : 9 ditegaskan:

"Dan hendaklah takut kepada Allah orang-orang yang seandainya meninggalkan dibelakang mereka anak-anak yang lemah, yang mereka khawatir terhadap (kesejahteraan) mereka. Oleh sebab itu hendaklah mereka bertakwa kepada Allah dan hendaklah mereka mengucapkan perkataan yang benar". (QS. Al-Nisa' [4] : 9)

Dalam konteks kehidupan rumah tangga disebutkan:

"Kaum laki-laki itu adalah pemimpin bagi kaum wanita, oleh karena Allah telah melebihkan sebahagian mereka (laki-laki) atas sebahagian yang lain (wanita), dan karena mereka (laki-laki) telah menafkahkan sebagian dari harta mereka. Sebab itu maka wanita yang saleh, ialah yang taat kepada Allah lagi memelihara diri ketika suaminya tidak ada, oleh karena Allah telah memelihara (mereka). Wanita-wanita yang kamu khawatirkan nusyuznya, maka nasehatilah mereka dan pisahkanlah mereka di tempat tidur mereka, dan pukullah mereka. Kemudian jika mereka mentaatimu, maka janganlah kamu mencari-cari jalan untuk menyusahkannya. Sesungguhnya Allah Maha Tinggi lagi Maha Besar". (QS. Al-Nisa' [4] : 34)

${ }^{82}$ Nunik widiyantoro, Konstruk Seksualitas dan Hak-hak Rreproduksi Perempuan, (Yogyakarta: Yayasan Kesehatan, 2001), h. 89

${ }^{83}$ Sri Siswati, Etika dan Hukum Kesehatan dalam Perspektif Undang-Undang Kesehatan, (Jakarta: PT Raja Grafindo Persada, 2013), cetakan pertama, h. 71 
Kedua ayat di atas kiranya dapat dengan jelas dipahami, pertama, agar dapat melahirkan keturunan yang sehat, maka syarat utama ia harus sehat juga. Kedua, ia perlu memiliki keimanan (ketakwaan) yang cukup. Karena dengan demikian ia dapat menjaga kesehatan mentalitasnya, dan tidak mudah terganggu oleh godaan-godaan lingkungannya. Ketiga, ia memiliki kejujuran untuk menyampaikan persoalan-persoalan yang dihadapinya kepada suaminya. Termasuk di dalamnya, soal hubungan suami-istri (seks), sehingga tidak akan terjadi eksploitasi (marital rape) dan pemerkosaan dalam rumah tangga. Keempat, suami (laki-laki) juga perlu memahami secara lebih baik soal-soal yang berkaitan dengan berumahtanggaan. ${ }^{84}$

Kesehatan reproduksi perempuan meliputi sekurang-kurangnya; 1) Maternal health (melahirkan dan sesudahnya), 2) penyakit saluran reproduksi (diseases of the reproductive tract) dari virus atau bakteri, 3) penggunaan alat kontrasepsi. Kesehatan reproduksi dapat diwujudkan jika ada saling pengertian dari kedua belah pihak, baik istri maupun terutama suami. Mengakhiri sketsa ini, dapat disimpulkan bahwa kesehatan reproduksi perempuan dalam perspektif Islam merupakan suatu keniscayaan..$^{85}$

Kesehatan reproduksi adalah kesehatan secara fisik, mental, dan kesejahteraan sosial secara utuh pada semua hal yang berhubungan dengan sistem dan fungsi, serta proses reproduksi yang bukan hanya kondisi yang bebas dari penyakit atau kecacatan. Definisi kesehatan reproduksi berarti bahwa setiap orang mampu memiliki kehidupan seksual yang memuaskan dan aman bagi dirinya, juga mampu menurunkan serta memenuhi keinginannya tanpa ada hambatan apapun, kapan, dan berapa sering untuk memilki keturunan. ${ }^{86}$

Pengertian kesehatan reproduksi ini ditemukan berbagai hal yang tercakup di dalamnya tentang berbagai hal sebagai berikut ini:

1. Hak seseorang untuk dapat memperoleh kehidupan seksual yang aman dan memuaskan serta mempunyai kapasitas untuk bereproduksi.

${ }^{84}$ Ahmad Rofiq, Figh Kontekstual dari Normatif ke Pemaknaan Sosial,(Yogyakarta: Pustaka Pelajar, 2004), cetakan 1, h. 59

${ }^{85}$ Ahmad Rofiq, Figh Kontekstual dari Normatif ke Pemaknaan Sosial,(Yogyakarta: Pustaka Pelajar, 2004), cetakan 1, h. 61

${ }^{86}$ Eny Kusmiran, dan Kesehatan Reproduksi Remaja Wanita,(Jakarta : Penerbit Salemba Medika, 2011), h. 94 
2. Kebebasan untuk memutuskan bilamana atau seberapa benyak melakukannya;

3. Hak dari laki-laki dan perempuan untuk memperoleh informasi serta memperoleh aksebilitas yang aman, efektif, terjangkau baik secara ekonomi maupun kultural;

4. Hak untuk mendapatkan tingkat pelayanan kesehatan yang memadai sehingga perempuan mempunyai kesempatan untuk menjalani proses kehamilan secara aman. ${ }^{87}$

Kesehatan reproduksi merupakan komponen penting kesehatan bagi pria maupun wanita, tetapi lebih dititikberatkan kepada wanita. Keadaan penyakit pada wanita lebih banyak dihubungkan dengan fungsi dan kemampuan bereproduksi serta tekanan sosial pada wanita karena masalah gender.

Kesehatan bagi wanita adalah lebih dari kesehatan reproduksi. Wanita memiliki kebutuhan kesehatan khusus yang berhubungan dengan fungsi seksual dan reproduksi. Wanita mempunyai sistem reproduksi yang sensitif terhadap kerusakan yang dapat terjadi disfungsi atau penyakit. Wanita adalah subjek dari beberapa penyakit terhadap fungsi tubuh oleh karena pengaruh laki-laki, pola penyakit pun berbeda dengan laki-laki karena adanya perbedaan bentuk genetik, hormonal, ataupun perilaku gaya hidup. Penyakit pada sistem tubuh ataupun pengobatan dapat berinteraksi dengan keadaan sistem reproduksi. ${ }^{88}$

Senada dengan definisi WHO sebagaimana yang di sampaikan oleh Kementrian Agama RI dalam Mushaf Al-Qur'an dalam Perspektif Al-Qur'an dan Sains Ilmi tentang kesehatan yaitu sehat jasmani, rohani, dan sosial, bukan hanya keadaan tidak sakit, maka WHO mendefinisikan kesehatan reproduksi kemampuan untuk menjalankan kehidupan seksual yang aman dan memuaskan serta kemampuan untuk memperoleh keturunan dalam jumlah yang diinginkan dan pada waktu yang ditentukan. Kesehatan reproduksi merupakan salah satu sasaran dari Millenium Development Goals (MGD). Keberhasilan ini diindikasikan melalui frekuensi penggunaan alat

87 Hasdianah Hasan Rohan dan Sandu Siyoto, Buku Ajar Kesehatan Reproduksi, (Yogyakarta : Nuha Medika, 2013), cetakan pertama, h. 1

${ }^{88}$ Eny Kusmiran, dan Kesehatan Reproduksi Remaja Wanita,(Jakarta : Penerbit Salemba Medika, 2011), h. 93 
kontrasepsi, jumlah ibu muda yang melahirkan, cakupan pelayanan selama kehamilan, dan pelayanan kontrasepsi yang tersedia. ${ }^{89}$

Dalam buku Remaja dan Kesehatan Reproduksi oleh Layyin Mahfiana menyebutkan faktor-faktor yang mempengaruhi kesehatan reproduksi secara garis besar dapat dikelompokkan empat faktor yang dampak berdampak buruk pada kesehatan reproduksi antara lain sebagai berikut:

a. Faktor Sosial-Ekonomi dan Demografi (terutama kemiskinan, tingkat pendidikan yang rendah, serta lokasi tempat tinggal yang terpencil);

b. Faktor budaya dan lingkungan (misalnya, praktik tradisional yang berdampak buruk pada kesehatan reproduksi, kepercayaan banyak anak banyak rezeki, informasi tentang fungsi reproduksi yang membingungkan anak dan remaja karena saling berlawanan satu sama lain, dsb);

c. Faktor psikologis (dampak dari keretakan orang tua pada remaja, depresi karena ketidakseimbangan hormonal, rasa tidak berharga wanita terhadap pria yang membeli kebebasannya dengan materi, $\mathrm{dsb})$;

d. Faktor biologis (cacat sejak lahir, cacat pada saluran reproduksi pasca PMS, dsb);

Pengaruh dari semua faktor di atas dapat dikurangi dengan strategi intervensi yang tepat guna, terfokus pada penerapan hak reproduksi perempuan dan pria dengan dukungan di semua tingkat administrasi, sehingga dapat diintegrasikan kedalam berbagai program kesehatan, pendidikan, sosial, dan pelayanan non-kesehatan lain yang terkait dalam pencegahan dan penanggulangan masalah kesehatan reproduksi. ${ }^{90}$

${ }^{89}$ Kementrian Agama RI Badan Litbang dan Diklat Lajnah Pentashihan Mushaf AlQur'an, Seksualitas Dalam Perspektif Al-Qur'an dan Sains Tafsir Ilmi, (Jakarta : Perpustakaan Nasional RI Katalog Dalam Terbitan, 2012), cetakan pertama, h. 14

90 Layyin Mahfiana dkk, Remaja dan Kesehatan Reproduksi, (Yogyakarta : STAIN Ponorogo Press, 2009), cetakan pertama, h. 41 


\section{Analisis Hukum Islam Terhadap PP No. 61 Tahun 2014 Tentang Kesehatan Reproduksi}

Dalam PP (Peraturan Pemerintah) No. 61 Tahun 2014 ini diatur, aborsi diperbolehkan dengan syarat dua kondisi saja. Pertama, hamil karena perkosaan, ketika usia kehamilan paling lama 40 hari. Kedua, karena indikasi darurat medis. Beberapa indikasi darurat medis, yakni mengancam nyawa ibu dan atau mengancam kesehatan janin karena kelainan genetik sehingga menyulitkan janin itu hidup di luar kandungan.

1. Kebolehan Aborsi Akibat Pemerkosaan dalam PP No. 61 Tahun 2014

Pemerkosaan dirumuskan secara hukum sebagai suatu tindakan persetubuhan yang dilakukan oleh seorang laki-laki terhadap seorang perempuan (yang bukan istrinya) dengan cara kekerasan atau ancaman kekerasan. Dalam pasal 285 KUHP menyebutkan: "Barang siapa dengan kekerasan atau dengan ancaman kekerasan memaksa seorang wanita yang bukan istrinya bersetubuh dengan dia, diancam karena melakukan perkosaan dengan pidana penjara paling lama dua belas tahun. ${ }^{91}$

Aborsi yang disebabkan oleh perkosaan diperbolehkan jika kelahiran anak tersebut dipastikan akan membawa dampak buruk bagi jiwa dan raga si ibu di kemudian hari. Aborsi untuk kasus seperti ini boleh, karena perempuan yang diperkosa bukan pelaku tindak pidana, sehingga rukhsah aborsi berlaku. Lebih-lebih perempuan itu hamil bukan atas kemauannya sendiri, melainkan dipaksa. $^{92}$

Selanjutnya kebolehan aborsi ini terdapat dalam pasal 34 sebagai berikut:

(1) Kehamilan akibat perkosaan sebagaimana dimaksud dalam pasal 31 ayat (1) huruf b merupakan kehamilan hasil hubungan seksual tanpa adanya persetujuan dari pihak perempuan sesuai dengan ketentuan peraturan perundang-undangan.

(2) Kehamilan akibat perkosaan sebagaimana dimaksud pada ayat (1) dibuktikan dengan :

${ }^{91}$ Neng Djubaedah, (Perzinaan Dalam Peraturan Perundang-undangan di Indonesia ditinjau dari Hukum Islam), (Jakarta: Kencana Prenada Media Group, 2010), Cetakan ke-1, h. 81

92 Ika Wahyuni Novianti (Dispensasi Aborsi Dalam PP No 61/2014 Menurut Tokoh Aisyiyah Muhammadiyah dan Tokoh Muslimat NU, 2014), Fakultas Syari'ah dan Hukum UIN Syarifhidayatullah Jakarta, h.58 
a. Usia kehamilan sesuai dengan kejadian perkosaan, yang dinyatakan oleh surat keterangan dokter, dan

b. Keterangan penyidik, psikolog, dan/atau ahli lain mengenai adanya dugaan perkosaan.

Berdasarkan ketentuan dalam PP No. 61 Tahun 2014 tersebut, hukum pidana dengan jelas menyebutkan sanksi pidana bagi pelaku yang turut serta melakukan aborsi. Pengecualian diberikan apabila ada alasan-alasan pembenar yang terdapat dalam undang-undang (pasal 44,48,50 dan 51) KUHP dan alasan medis (kesehatan) yang terdapat dalam pasal 31 PP No. 61 tahun 2014 tentang Kesehatan Reproduksi. Dengan demikian alasan ekonomis, alasan sosial dan alasan darurat (pemaksa) tidak dapat dijadikan legalisasi dari perbuatan abortus provocatus.

Apabila dihubungkan dengan aborsi karena kehamilan tidak dikehendaki (KTD) akibat perkosaan, dimana kehamilan akibat perkosaan yang dapat menyebabkan trauma psikologis bagi korban perkosaan dapat dijadikan sebagai alasan darurat (pemaksa) untuk melakukan aborsi sebenarnya perlu menjadi pertimbangan dalam menerapkan sanksi pidana, khususnya bagi para penegak hukum (Hakim) karena janin yang di aborsi adalah sebagai akibat pemaksaan hubungan (perkosaan) dengan ancaman kekerasan. Perkosaan sendiri merupakan tindak pidana pelakunya harus dijatuhi sanksi pidana penjara maksimal 12 (dua belas) tahun sesuai pasal 285 KUHP. Sedangkan korbannya harus mendapat perlindungan hukum yang salah satu caranya adalah mengembalikan kondisi jiwa akibat tekanan daya paksa dari pihak lain (tekanan psikologis). Alasan tekanan psikologis akibat perkosaan inilah yang seharusnya dapat dijadikan pertimbangan untuk menentukan bahwa aborsi akibat perkosaan sebagai suatu pengecualian, sehingga seharusnya legal dilakukan..$^{93}$ Perkosaan bukan hanya menimbulkan dampak psikologis yang luar biasa bagi korban, namun sering kali menimbulkan trauma dan kepedihan yang sangat mendalam. Pada sebagian korban, mungkin kengerian itu akan terus membayang-bayangi hidupnya.

Menurut jumhur fuqaha sebagaimana di kutip dalam buku Pelaku Zina Pandangan Hukum Islam dan KUHP oleh Muhammad Abduh Malik kehamilan bukanlah merupakan bukti yang mandiri tapi harus disertai pengakuan atau keterangan bukti-bukti lain. Menurut Imam Malik jika wanita itu dalam

\footnotetext{
${ }^{93}$ Ika Wahyuni Novianti, Dispensasi Aborsi,( Jakarta: UIN, 2014), h. 60
} 
pengakuannya dia dipaksa (diperkosa), maka wanita itu harus menunjukan tanda-tanda bukti bahwa dia dipaksa. ${ }^{94}$

Menurut pendapat Imam Malik, apabila seorang wanita hamil dan dia tidak bisa menunjukkan bahwa dia punya suami atau dia dipaksa orang, maka wanita tersebut dijatuhi hukuman hadd. Jika wanita itu perempuan bikr (perawan), dia harus bisa menunjukkan bukti pendarahannya sebagai bukti bahwa dia telah diperkosa untuk bisa dibebaskan dari hukuman hadd. Umar bin Khattab pernah mengatakan: Apabila ada bukti atau kehamilan atau pengakuan, maka pelaku zina pria dan wanita muhsan wajib dikenai hukuman rajam..$^{95}$

Pemerintah RI melalui PP No. 61 Tahun 2014 tentang kesehatan reproduksi menghalalkan aborsi akibat perkosaan. Hal ini cukup mengagetkan banyak pihak, khususnya ulama dan kaum muslimin yang selama ini berpandangan aborsi hukumnya haram. Penghalalan aborsi akibat perkosaan ini dapat dilihat dalam pasal $31 \mathrm{PP}$ ayat 1 yang berbunyi: tindakan aborsi hanya dapat dilakukan berdasarkan a) indikasi kedaruratan medis; atau b) kehamilan akibat perkosaan. Selanjutnya, ayat (2) pasal ini menyatakan tindakan aborsi akibat perkosaan sebagaimana dimaksud pada ayat 1 huruf $b$ hanya dapat dilakukan pada usia kehamilan paling lama berusia 40 hari sejak hari pertama haid terakhir. ${ }^{96}$

PP No 61 ini dapat membuka peluang kasus aborsi dengan alasan akibat perkosaan jika tidak dilengkapi dengan peraturan perundangundangan yang jelas dengan berbagai indikasi gamblang yang mudah dipahami semua pihak. Sementara itu, pada pasal 34 PP ini dinyatakan bahwa:

1. Kehamilan akibat perkosaan sebagaimana dimaksud dalam pasal 31 ayat 1 huruf $b$ merupakan kehamilan hasil hubungan seksual tanpa adanya persetujuan dari pihak perempuan sesuai dengan ketentuan peraturan perundang-undangan. Selanjutnya mengenai pembuktian

${ }^{94}$ Muhammad Abduh Malik, (Perilaku Zina Pandangan Hukum Islam dan KUHP), (Jakarta: PT. Bulan Bintang, 2003), cetakan pertama, h. 134

${ }_{55}$ Mustopa Dib Al-Baqa, At-Tadhib Fii Adhilati Matan Al-Qoyah Wal Taqrif, (Surabaya: Toko Kitab Al-Hidayah), TTH., H. 204

${ }^{96}$ M. Nurul Irfan, Gratifikasi dan Kriminalitas Seksual dalam Hukum Pidana Islam, (Jakarta: AMZAH, 2014), cetakan pertama, h. 104 
bahwa seorang wanita benar-benar mengalami perkosaan hingga ia hamil dan korban perkosaan ini dibenarkan melakukan aborsi, dikemukakan pada ayat selanjutnya bahwa;

2. Kehamilan akibat perkosaan sebagaimana dimaksud pada ayat 1 dibuktikan dengan;

a. Usia kehamilan sesuai dengan kejadian perkosaan, yang dinyatakan oleh surat keterangan dokter

b. Keterangan penyidik, psikolog, dan/atau ahli lain mengenai adanya dugaan perkosaan.

Rumusan peraturan diperbolehkannya tindakan aborsi bagi wanita korban perkosaan ini memang sudah sangat jelas, yaitu bahwa wanita itu benar-benar sebagai korban perkosaan. Dalam hal ini tidak dapat dibenarkan dengan sekedar mengaku bahwa ia telah menjadi korban perkosaan. Ia harus membuktikan bahwa ia benar-benar di perkosa oleh seorang laki-laki dengan melibatkan keterangan dari dokter, penyidik atau psikolog. Oleh sebab itu, untuk melakukan aborsi yang legal berdasarkan PP No. 61 Tahun 2014 ini tidak mudah dan tidak cukup dengan mengaku diperkosa. ${ }^{97}$

Penanggulangan kehamilan akibat perkosaan dengan cara pengguguran kandungan dilihat dari sudut pandang hukum pidana sampai saat ini masih dikategorikan sebagai tindak kejahatan, meskipun dilakukan oleh dokter ahli kebidanan dan penyakit kandungan dengan indikasi medik. Pengaturan hukum yang khusus yang berisi kaidah-kaidah tentang pengguguran kandungan, hanya diatur secara garis besarnya saja di dalam satu pasal didalam Undang-undang No. 23 tentang Kesehatan, yaitu pasal $15 .{ }^{98}$

Indikasi Kedaruratan Medis dan Perkosaan sebagai Pengecualian atas Larangan Aborsi terdapat dalam PP No. 61 Tahun 2014. Berdasarkan indikasi medis yang mengharuskan diambilnya tindakan tersebut, oleh tenaga kesehatan yang mempunyai keahlian dan kewenangan untuk itu dan dilakukan sesuai dengan tanggung jawab profesi serta

${ }^{97}$ M. Nurul Irfan, Gratifikasi dan Kriminalitas Seksual dalam Hukum Pidana Islam, (Jakarta: AMZAH, 2014), cetakan pertama, h. 105

98 Wila Chandrawila Supriadi, Hukum Kedokteran, ( Bandung : Mandar Maju, 2001), cetakan pertama, h.78 
berdasarkan pertimbangan tim ahli, dan dengan persetujuan ibu hamil yang bersangkutan atau suami atau keluarganya. ${ }^{99}$

Pengguguran kandungan telah mendapatkan pengaturan juga di dalam pasal 15 UU No. 23 Tahun 1992 yang bunyinya:

1. Dalam keadaan darurat sebagai upaya menyelamatkan nyawa ibu hamil dan janinnya, dapat dilakukan tindakan medik tertentu.

2. Tindakan medik tertentu sebagaimana dimaksud dalam ayat (1) hanya dapat dilakukan:

a. Berdasarkan indikasi medik yang mengharuskan diambilnya tindakan tersebut;

b. Oleh tenaga kesehatan yang mempunyai keahlian dan kewenangan untuk itu dilakukan sesuai dengan tanggungjawab profesi serta berdasarkan pertimbangan tim ahli;

c. Dengan persetujuan ibu hamil yang bersangkutan atau suami keluarganya;

d. Pada sarana kesehatan tertentu

3. Ketentuan lebih lanjut mengenai tindakan medik tertentu sebagaimana dimaksud dalam ayat (1) dan ayat (2) ditetapkan dengan Peraturan Pemerintah. Penjelasan pasal 15 UU No. 23 Tahun 1992 menerangkan sebagai berikut:

\section{Ayat (1)}

Tindakan medik dalam bentuk apapun, pengguguran kandungan dengan alasan apapun, dilarang karena bertentangan dengan norma hukum, norma agama, noram kesusilaan dan norma kesopanan. Namun, dalam keadaan darurat sebagai upaya menyelamatkan jiwa ibu dan atau bayi yang dikandungnya dapat diambil tindakan medik tertentu.

\section{Ayat (2)}

Butir a

${ }^{99}$ Budi Utomo dkk, Angka Aborsi dan Aspek Psiko-sosial di Indonesia: Studi di 10 kota Besar dan 6 kabupaten. (Jakarta: Pusat Penelitian Kesehatan Universitas Indonesia, 2002), h. 7 
Indikasi medik adalah suatu kondisi yang benar-benar mengharuskan diambil tindakan medik tertentu, sebab tanpa tindakan medik tertentu ibu hamil dan atau janinnya terancam bahaya maut.

Butir b

Tenaga kesehatan yang dapat melakukan tindakan medik tertentu adalah tenaga yang memiliki keahlian dan kewenangan untuk melakukannya yaitu seorang dokter ahli kebidanan dan penyakit kandungan.

Butir c

Hak utama untuk memberikan persetujuan ada pada ibu hamil yang bersangkutan kecuali dalam keadaan tidak sadar atau tidak dapat memberikan persetujuannya, dapat diterimaa dari suami atau keluarganya.

Butir d

Saran kesehatan tertentu adalah sarana kesehatan yang memiliki tenaga dan peralatan yang memadai untuk tindakan tersebut dan ditunjuk oleh pemerintah.

\section{Ayat (3)}

Dalam peraturan pemerintah sebagai pelaksanaan dari pasal ini dijabarkan antara lain mengenai keadaan darurat dalam menyelamatkan jiwa ibu hamil dan atau janinnya, tenaga kesehatan yang mempunyai keahlian dan kewenangan, bentuk persetujuan dan sarana kesehatan yang ditunjuk. ${ }^{100}$

PP No. 61 Tahun 2014 tentang kesehatan reproduksi ini rawan disalahgunakan oleh banyak pihak sehingga terjadi kesepakatan yang menyimpang antara lain wanita hamil, oknum dokter, dan oknum penyidik. Oknum dokter dan oknum penyidik bisa saja bersekongkol melakukan aborsi, terlebih lagi wanita yang hamil tersebut berasal dari keluarga berada. Selanjutnya, karena PP ini telah disahkan untuk disosialisasikan dan diberlakukan, maka wajib diikuti dengan tata aturan yang jelas, memadai dan mudah dimengerti oleh masyarakat. Jika tidak, sebagian warga masyarakat

100 Wila Chandrawila Supriadi, Hukum Kedokteran, (Bandung: Mandar Maju, 2001), cetakan pertama, h. 76-77 
merasa mendapat angin segar dengan adanya legalisasi aborsi akibat perkosaan ini. ${ }^{101}$

Hal mendasar lain yang harus disosialisasikan kepada masyarakat adalah tentang maraknya kasus hamil luar nikah sekaligus kehamilan yang tidak dikehendaki. Akibatnya, aborsi juga marak terjadi. Semua hal ini berpangkal dari pergaulan bebas antar remaja yang dapat mengakibatkan perzinaan. Sementara itu, delik perzinaan hanya termasuk dalam kategori delik aduan karena rumusan Pasal 284 KUHP sejak tahun 1915 hingga saat ini tidak pernah direvisi. Pada masa akhir periode DPR-RI tahun 2014, rancangan UU tentang KUHP pernah mencuat, tetapi kemudian dalam waktu sekejap sirna kembali. Jika draf baru KUHP ini disahkan, pasal 284 KUHP menjadi pasal 484 dan akan menjadi pedoman dalam mengatur hubungan badan di luar nikah. Dengan demikian, angka perzinaan dapat ditekan sehingga jumlah kasus hamil di luar nikah dan aborsi juga dapat diminimalkan. ${ }^{102}$

Menurut penulis rumusan pasal tentang tindak pidana perzinaan adalah perzinaan yang dilakukan oleh dua orang yang salah satu atau keduanya terikat perkawinan yang sah dan adanya pengaduan dari pihak istri atau suami pelaku zina dan dilakukan atas dasar suka sama suka. Hukumannya adalah maksimal sembilan bulan penjara. Akibat dari perzinaan ini tentu saja akan semakin maraknya melakukan tindakan aborsi karena salah satu melakukan aborsi ini yaitu perzinaan tersebut yang menghasilkan kehamilan yang tidak diinginkan. Pergaulan bebas masyarakat modern sangat rentan terhadap perilaku aborsi. Hukuman aborsi juga tidak berpengaruh bagi pelaku tindak pidana aborsi karena hanya di penjara atau bayar denda, maka dari itu untuk meminimalisir terjadinya aborsi perlu melihat pada hukum pidana Islam agar masyarakat berpikir panjang untuk melakukan aborsi ini mengingat hukuman yang diterapkan sangat berat, karena jika tidak mengacu pada hukum Islam angka aborsi itu semakin tahun semakin meningkat, bukan pelaku saja yang melakukan tindakan ini tapi instansi pemerintah juga ikut serta dalam melakukan perbuatan ini, misalnya dokter meminta imbalan yang sangat besar untuk melakukan praktik aborsi dengan memalsukan surat keterangan dll.

101 M. Nurul Irfan, Gratifikasi dan Kriminalitas Seksual dalam Hukum Pidana Islam, (Jakarta: AMZAH, 2014), cetakan pertama, h. 107

${ }_{102}$ M. Nurul Irfan, Gratifikasi dan Kriminalitas Seksual dalam Hukum Pidana Islam, h. 108 
2. Kebolehan Aborsi Akibat Kedaruratan Medis dalam PP No. 61 Tahun 2014

Pengguguran kandungan (tindakan medik tertentu) menurut pasal 23 itu hanya boleh dilakukan dalam "keadaan darurat" untuk " menyelamatkan jiwa ibu hamil". Penjelasan lebih lanjut mengenai indikasi medik; suatu kondisi yang benar-benar mengharuskan diambil tindakan pengguguran kandungan, sebab kalau tidak ibu hamil terancam bahaya maut.

Mengenai indikasi medik dan menyelamatkan jiwa ibu hamil, seringkali menjadi bahan perdebatan, sebab Undang-undang hanya menyebutkan kondisi yang benar-benar mengharuskan diambil tindakan pengguguran kandungan, kalau tidak jiwa ibu hamil sebagai taruhannya. Terkait dengan maksud di atas dalam menafsirkan pasal 15 UU No. 23/92 menyatakan pertama:

"bahwa yang dimaksud dengan kondisi yang benar-benar mengharuskan dilakukan tindakan pengguguran kandungan, adalah secara fisik ibu hamil terancam bahaya maut bila tidak dilakukan pengguguran kandungan". Kedua dalam menafsirkan pasal 15 UU No. 23/92 menyatakan :"bahwa yang dimaksud dengan kondisi yang benar-benar mengharuskan dilaksanakan pengguguran kandungan adalah secara fisik ataupun secara psikis ibu hamil terancam bahaya maut bila pelaksanaan pasal $15 \mathrm{UU}$ No, 23/92 menyebabkan ketidakpastian hukum, sebab banyak kesehatan menjadi takut melakukan tindak pengguguran kandungan bila tidak berdasarkan indikasi medik secara fisik. ${ }^{103}$

Aborsi yang penggugurannya dilakukan oleh tenaga medis disebabkan faktor adanya indikasi medis. Biasanya aborsi jenis ini dilakukan dengan mengeluarkan janin dari rahim meskipun jauh dari masa kelahirannya. Aborsi jenis ini dilakukan sebagai tindakan penyelamatan jiwa seorang ibu setelah pemeriksaan secara medis karena jika kehamilannya dipertahankan akan membahayakan dan mengancam kesehatan ataupun keselamatan nyawa ibunya. Aborsi ini dikalangan ulama disebut dengan istilah al-isqath al dharuri atau dengan al-isqath al-ilajiy yang berarti aborsi darurat atau aborsi pengobatan. ${ }^{104}$

103 Wila Chandrawila Supriadi, Hukum Kedokteran, ( Bandung : Mandar Maju, 2001), cetakan pertama, h. 79

${ }^{104}$ Sahal Mahfudh, Figh Sosial; Upaya Pengembangan Mazhab Qouli dan Mazhab Manhaji, (Jakarta: UIN, 2003), h. 23 
Selanjutnya mengenai aborsi yang dilakukan dalam keadaan benarbenar terpaksa yaitu demi menyelamatkan nyawa si ibu, maka Islam membolehkan, bisa jadi wajib karena Islam mempunyai prinsip yang dalam kaidah fikihnya.

"Jika dihadapkan pada dua kondisi yang sama-sama membahayakan, maka pilihlah bahaya yang lebih kecil risikonya".

Menurut pandangan Islam, aborsi dilakukan sesudah janin bernyawa atau berumur empat bulan, keharaman aborsi ini dipandang sebagai pembunuhan terhadap manusia. Tetapi apabila aborsi dilakukan karena benar-benar terpaksa demi menyelamatkan si ibu, maka Islam membolehkan, karena Islam mempunyai prinsip

"Menempuh salah satu tindakan yang lebih ringan dari pada hal yang berbahaya, itu wajib hukumnya". ${ }^{105}$

Aborsi juga yang dilakukan oleh dokter dalam rangka menyelamatkan ibu yang akan melahirkan dengan jalan mematikan bayi yang dikandungnya, pada saat diketahui proses kelahiran bayi itu mengakibatkan hilangnya nyawa si ibu, ini dibolehkan karena keadaan darurat berdasarkan kaidah berikut ini:"106 "Keadaan darurat dapat membolehkan perbuatan yang dilarang".

Jadi hukum Islam membolehkan untuk melakukan aborsi dengan mengorbankan janin karena menyelamatkan nyawa ibu yang terdapat dalam PP No 61 tahun 2014. Nyawa ibu diutamakan, mengingat dia merupakan sendi keluarga dan telah mempunyai hak dan kewajiban, baik terhadap sesama makhluk, sedangkan si janin (bayi), sebelum ia lahir dalam keadaan hidup, ia belum mempunyai hak seperti hak waris dan belum mempunyai kewajiban apapun. ${ }^{107}$

Menurut Ahmad Sudirman Abbas dalam bukunya yang berjudul Qawaid Fiqhiyyah dalam Perspektif Fiqh menyebutkan apabila dlarar

105 M. Ali Hasan, Masail Fighiyyah Al- Haditsah Pada Masalah-Masalah Kontemporer Hukum Islam, (Jakarta: PT Raja Grafindo Persada, 2000 ), Cet 4, h. 52

106 M. Ali Hasan, Masail Fighiyyah Al- Haditsah Pada Masalah-Masalah Kontemporer Hukum Islam, (Jakarta: PT Raja Grafindo Persada, 2000 ), Cet 4, h. 55

107 Huzaimah Tahido Yanggo, Masail Fighiyyah Kajian Hukum Islam Kontemporer, (Bandung: Angkasa Bandung, 2005), cetakan pertama, h. 111 
tersebut lebih besar dari pada yang lainnya, maka berlaku kaidah;108 "Dlarar yang lebih besar dihilangkan dengan dlarar yang lebih ringan".

Kaidah ini menegaskan bahwa untuk menghilangkan suatu bahaya disyaratkan harus tidak menimbulkan bahaya yang lain. Suatu bahaya bisa saja dihilangkan dengan menimbulkan bahaya yang lain, jika kadar bahaya yang ditimbulkannya tidak seimbang dan tidak lebih besar dari pada bahaya yang dihilangkan. Oleh karena itu, seseorang yang hendak menghilangkan suatu bahaya, harus memperhitungkan terlebih dahulu dampak yang akan ditimbulkan. Apabila dampaknya seimbang atau bahkan lebih besar dari bahaya yang hendak dihilangkan, maka ia harus mengurungkan niatnya, namun apabila dampak yang ditimbulkan lebih kecil daripada bahaya yang dihilangkan, maka ia bebas meneruskan niatnya. ${ }^{109}$

Apabila aborsi dilakukan karena sebab-sebab lain yang sama sekali tidak terkait dengan keadaan darurat, seperti untuk menghindarkan rasa malu atau karena faktor ekonomi, maka hukumnya haram alasannya adalah firman Allah SWT dalam surah An-Nahl [16] : 58-59

“Dan apabila seseorang dari mereka diberi kabar dengan (kelahiran) anak perempuan, hitamlah (merah padamlah) mukanya, dan dia sangat marah."(QS. An-Nahl [16] : 58)

“Ia menyembunyikan dirinya dari orang banyak, disebabkan buruknya berita yang disampaikan kepadanya. Apakah dia akan memeliharanya dengan menanggung kehinaan ataukah akan menguburkannya ke dalam tanah (hidup-hidup)? Ketahuilah, alangkah buruknya apa yang mereka tetapkan itu." QS. An-Nahl [16] : 59)

Dalam ayat di atas Allah SWT kebiasaan orang arab jahiliah yang merasa malu mendapat anak perempuan, sehingga mereka sampai hati untuk menguburnya hidup-hidup hanya karena merasa malu. Ulama Fikih menganalogikan apa yang dilakukan oleh orang-orang jahiliah ini dengan pengguguran kandungan karena rasa malu. Tindakan aborsi karena pertimbangan faktor ekonomi juga di kecam oleh Allah SWT dalam surah AlIsra' [17] : 31,

108 Ahmad Sudirman Abbas, Qawaid Fighiyyah Dalam Perspektif Fiqh, (Jakarta: Pedoman Ilmu Jaya, dengan Anglo Media Jakarta, 2004), cetakan pertama, h. 139

${ }^{109}$ Ahmad Sudirman Abbas, Qawaid Fighiyyah Dalam Perspektif Figh, (Jakarta: Pedoman Ilmu Jaya, dengan Anglo Media Jakarta, 2004), cetakan pertama, h. 140 
"Dan janganlah kamu membunuh anak-anakmu karena takut kemiskinan. Kamilah yang akan memberi rezeki kepada mereka dan juga kepadamu. Sesungguhnya membunuh mereka adalah suatu dosa yang besar.( QS. AlIsra'[17]: 31)

“Orang-orang yang sabar (terhadap bencana), dan mengerjakan amal-amal saleh; mereka itu beroleh ampunan dan pahala yang besar". .( QS. Hud [11]: 6)

Sebab dalam Hud [11]: 6, Allah swt menyatakan tidak ada makhluk hidup yang tidak disediakan sumber rezekinya oleh Allah SWT. ${ }^{110}$

Para ulama Indonesia membicarakan persoalan aborsi dan tetap berdasarkan persoalan pada keputusan ulama fikih klasik, yakni aborsi itu haram dilakukan. Kecuali ada alasan medis sebagai menifestasi kaidah (Jika ada pertentangan dua mafsadah (bahaya), maka harus dipilih paling kecil resikonya). ${ }^{111}$ Oleh karena itu, mereka berpandangan ketika terjadi pertentangan antara bahaya jiwa yang akan menimpa si ibu dan anaknya, yang didahulukan adalah membela jiwa ibunya. ${ }^{112}$

Dilema kematian antara ibu dan janin dalam pandangan fuqaha di pecahkan melalui pengorbanan janin berdasarkan kaidah di atas:113 Dari penjelasan di atas kaitannya dalam masalah ini, bahwa menghindari perbuatan yang membahayakan jiwa ibu lebih diutamakan dari pada melakukan aborsi, terlebih aborsi dilakukan tanpa alasan yang kuat.

Pemerintah RI memberi respon tentang masalah aborsi akibat pemerkosaan dan kedaruratan medis dengan PP No. 61 Tahun 2014 tentang kesehatan reproduksi. Dalam PP tersebut, permasalahan aborsi memperoleh legitimasi dan penegasan. Secara eksplisit, dalam PP ini terdapat pasal-pasal yang mengatur mengenai aborsi, meskipun dalam praktik medis mengundang berbagai reaksi dan menimbulkan kontroversi diberbagai lapisan masyarakat. Meskipun, undang-undang melarang praktik aborsi,

110 Hafiz Dasuki, Ensiklopedi Hukum Islam, (Jakarta: PT Ichtiar Baru Van Hoeve, 1997),

Cetakan pertama, h. 9

${ }^{111}$ Muhammad Sidqi Bin Ahmad Al-Burniu, Al-Waziz Fi Idah Qawaidul Fighi Al-Quliah, (Riat: Muasasah Ar-Risalah), h. 83

112 M. Ikhsanudin, (Jika Ulama Mengkaji Aborsi Antara Muhammmadiyah dan NU), ( Yogyakarta: Universitas Gajah Mada, 2005),cetakan pertama, h. 107

113 A. Djazuli, (Kaidah-Kaidah Fikih: Kaidah-Kaidah Hukum Islam dalam Menyelesaikan Masalah-Masalah yang Praktis), (Jakarta: Kencana, 2007), cetakan kedua, h. 74 
tetapi dalam keadaan tertentu terdapat kebolehan ketentuan pengaturan aborsi dalam PP No. 61 Tahun 2014 dituangkan dalam pasal 31, 32, 33.

Secara prinsipnya negara tidak membolehkan aborsi dilegalkan dengan alasan apapun. Kecuali, mengganggu jiwa ibu atau keselamatannya. Pendapat para ulama pun hukum aborsi itu pada dasarnya haram. Tetapi dalam suatu keadaan tertentu adanya suatu hukum pengecualian. Pengecualian itu adalah adanya ancaman bagi pihak ibu atau janin sehingga diperbolehkan menggugurkan kandungannya sebelum janin berumur 40 hari.

Baik aborsi itu dilakukan di fase awal janin atau setelah ditiupkannya ruh. Sebab semua fase pembentukan janin berisi kehidupan yang harus dihormati, yaitu kehidupan pertumbuhan dan pembentukannya. Hal ini menyelisihi orang-orang yang membolehkan aborsi sebelum ruh ditiupkan. Mereka beranggapan bahwa sebelum adanya ruh maka tidak ada kehidupan padanya. Sehingga tidak ada kejahatan dan keharaman. Dengan membolehkan hal itu berarti mereka telah membuka pintu yang sulit dibendung dan memberikan senjata pada tangan lawan dan musuh Islam untuk mencela Islam. Juga melegalkan semua yang terjadi diluar Negara Islam yang berupa perbuatan nista dan tercela. Setelah dipastikan secara ilmiah bahwa aborsi memiliki bahaya bagi kesehatan dari kehidupan wanita, sehingga aborsi diharamkan untuk dilakukan, karena menghilangkan mudharat lebih didahulukan dari mengambil kemaslahatan. ${ }^{114}$

Namun demikian, fikih selalu mengenal pengecualian. Demikian pula halnya dengan aborsi. Hukum aborsi yang telah diformulasikan oleh para fuqaha berlaku dalam kondisi normal. Dalam ranah pengecualian memperbolehkan bahkan mewajibkan aborsi, jika terjadi sebuah kondisi yang dianggap "dharurat”. Banyak ayat Al-Qur'an dan Kaidah Fikih yang menjadi sandaran hukum mengenai hal ini, seperti dalam surat al-Baqarah ayat 173 (QS. Al-Baqarah [2] : 173)

"Sesungguhnya Allah hanya mengharamkan bagimu bangkai, darah, daging babi, dan binatang yang (ketika disembelih) disebut (nama) selain Allah. Tetapi barangsiapa dalam keadaan terpaksa (memakannya) sedang dia tidak menginginkannya dan tidak (pula) melampaui batas, maka tidak ada dosa baginya. Sesungguhnya Allah Maha Pengampun lagi Maha Penyayang".

${ }^{114}$ Muhammad Sidqi Bin Ahmad Al-Burniu, Al-Waziz Fi Idah Qawaidul Fighi Al-Quliah, (Riat: Muasasah Ar-Risalah), h. 85 
Berdasarkan penjelasan di atas, pasal tentang aborsi yang diatur dalam Kitab Undang-Undang Hukum Pidana juga bertentangan dengan pasal 31 PP No 61 thn 2014 tentang Kesehatan Reproduksi, dimana dalam satu sisi melarang dilakukannya aborsi dalam segala alasan dan di sisi lain memperbolehkan tetapi atas indikasi medis untuk menyelamatkan ibu hamil dan atau janin.

Berdasarkan ketentuan PP No. 61 tahun 2014 jika dikaitkan dengan aborsi karena kedaruratan medis, maka dapat disimpulkan; Pertama, secara umum praktik aborsi dilarang; Kedua, larangan terhadap praktik dikecualikan pada beberapa keadaan, apabila terdapat indikasi medis yang dideteksi sejak usia dini kehamilan. Baik yang mengancam nyawa ibu dan atau janin yang menderita penyakit genetik berat dan/atau cacat bawaan, maupun yang tidak dapat diperbaiki sehingga menyulitkan bayi tersebut hidup di luar kandungan. Selain itu tindakan medis terhadap aborsi karena adanya indikasi kedaruratan medis yakni demi menyelamatkan nyawa ibu. Syarat-syaratnya yaitu:

a. Dilakukan oleh tenaga kesehatan dan memiliki keahlian dan kewenangan untuk melakukannya (yaitu seorang dokter ahli kebidanan dan penyakit kandungan) sesuai tanggung jawab profesi.

b. Harus meminta pertimbangan tim ahli (ahli medis lain, agama, hukum, psikologi dan lain-lain).

c. Harus ada persetujuan tertulis dari penderita atau suaminya atau keluarganya terdekat.

d. Dilakukan di sarana kesehatan yang memilki tenaga atau peralatan yang memadai, yang ditunjuk oleh pemerintah prosedur tidak dirahasiakan.

e. Dokumen medis harus lengkap. ${ }^{115}$

\section{Penutup}

Mengapa diperbolehkannya aborsi akibat pemerkosaan dan kedaruratan medis? Menurut hukum Islam pada hakekatnya praktik aborsi tidak di perbolehkan atau dilarang karena sama saja dengan membunuh februari 2016

115 Definisi aborsi". Artikel diskses http://www.google.com/search pada tanggal 15 
manusia namun apabila aborsi tersebut merupakan upaya untuk melindungi atau menyelamatkan si ibu, maka hukum Islam memperbolehkan bahkan mengharuskan. Kebolehan aborsi diatur dalam PP No. 61 Tahun 2014 tentang Kesehatan Reproduksi yang terdapat dalam pasal 31 ayat (1) huruf b dan pasal 34 .

Pengguguran kandungan atau aborsi dalam hukum pidana Islam termasuk dalam pembunuhan syibh amd yang sekalipun dilakukan dalam berbagai alasan apapun tetap sebagai tindak pidana dengan pemberian sanksi pidana penjara. Mengenai batasan pengguguran kandungan atau aborsi akibat kedaruratan medis sudah jelas di atur dalam PP No. 61 Tahaun 2014 tentang Kesehatan Reproduksi. Dalam PP ini tindakan pengguguran kandungan diberikan pengecualian dengan alasan kepentingan kesehatan karena pada dasarnya kesehatan itu lebih penting terutama kesehatan pada perempuan mengenai alat reproduksinya. Meskipun dalam ketentuan Peraturan Pemerintah (PP) tersebut Kesehatan Reproduksi memperbolehkan tindakan aborsi akibat Kedaruratan Medis. Solusi hukum terhadap kehamilan yang tidak diharapkan akibat pemerkosaan adalah tetap mempertahankan janin apabila keadaan si ibu normal atau sehat dan menyakinkan untuk mengandung janinnya akan tetapi berbeda halnya dengan pengguguran kandungan akibat kedaruratan medis tersebut akan mengancam keselamatan jiwa si ibu, maka Aborsi dapat dilakukan tetapi harus diperhatikan benarbenar kehamilan tersebut berbahaya bagi si ibu.

Menurut jumhur fuqaha ghurrah (denda) yang wajib dibayar karena membunuh janin mempunyai harga terbatas yaitu separuh dari sepersepuluh diyat ibunya, jadi ghurrah nilainya sama dengan lima ekor unta, karena praktik perbudakan sudah tidak dijumpai lagi pada kehidupan zaman sekarang, maka hukuman bagi pelaku yang tadinya dikenakan membayar gurrah budak dapat diganti seharga lima ekor unta. Ghurrah menurut arti asalnya adalah khiyar (pilihan), hamba sahaya disebut ghurrah karena merupakan harta pilihan. Dalam praktiknya ghurrah ini dinilai dengan lima ekor unta, atau yang sebanding dengan itu, yaitu lima puluh dinar, atau lima ratus dhirham, atau enam ratus dirham. Dalam tindak pidana atas janin yang dilakukan dengan sengaja menurut ulama malikiyah diyat ghurrahnya diperberat (mughalladzah) dan untuk tindak pidana atas janin yang menyerupai sengaja ghurrah dapat diringankan (mukhaffafah). 


\section{Pustaka Acuan}

'Abd al-Rahim 'Umran, Islam dan KB (Jakarta: PT. LENTERA BASRITAMA Anggota IKAPI, 1992), cetakan pertama.

A. Djazuli, (Kaidah-Kaidah Fikih: Kaidah-Kaidah Hukum Islam dalam Menyelesaikan Masalah-Masalah yang Praktis), (Jakarta: Kencana, 2007),cetakan kedua.

A. Djazuli, Figh Jinayah Upaya Menanggulangi Kejahatan Dalam Islam, (Jakarta: Raja Grafindo Persada, 1997).

A. Hanafie, Ushul Fiqh, ( Jakarta: Widjaya, 1962), Cetakan Ke-3.

Abbas Syauman, Hukum Aborsi Dalam Islam, (Jakarta: Cendekia Sentra Muslim Anggota IKAPI), 2004, cetakan pertama.

Abbas Syauman, Hukum Aborsi Dalam Islam, (Jakarta: Cendekia Sentra Muslim Anggota IKAPI), 2004, cetakan pertama.

Abd al-Qadir Manshur, Buku Pintar Fikih Wanita (Segala Hal Yang Ingin Anda Ketahui Tentang Perempuan dalam Hukum Islam), (Jakarta: Zaman, 2009), cetakan pertama.

Abdul Azis Dahlan, Ensiklopedia Hukum Islam, (Jakarta: PT. Ichtiar Baru Van Hoeve, 1996), cet 1 .

Abdul Qadir Audah, Ensiklopedia Hukum Pidana Islam II, ( At-Tasyri' alJinaiy al-Islamiy Muqaranan bil Qanunil Wad'iy, Bab Aborsi ), (Jakarta: PT. Kharisma Ilmu, diterjemahkan oleh Tim Salsilah, 2006.

Abdul Qadir Audah, Ensiklopedia Hukum Pidana Islam II, (PT. Kharisma Ilmu), ( At-Tasyri' al-Jinaiy al-Islamiy Muqaranan bil Qanunil Wad'iy, Bab Aborsi.

Abul Fadl Mohsin Ebrahim, Aborsi Kontrasepsi dan Mengatasi Kemandulan (Isu-isu Biomedis Dalam Perspektif Islam. (Bandung : Penerbit Mizan Anggota IKAPI, 1997.

Ahmad Rofiq, Figh Kontekstual dari Normatif ke Pemaknaan Sosial,(Yogyakarta: Pustaka Pelajar, 2004), cetakan 1.

Ahmad Sudirman Abbas, Qawaid Fighiyyah Dalam Perspektif Figh, (Jakarta: Pedoman Ilmu Jaya, dengan Anglo Media Jakarta, 2004), cetakan pertama.

Ahmad Wardi Muslich, Hukum Pidana Islam, (Jakarta: Sinar Grafika, 2005), cetakan pertama.

Al-Faqih Abul Wahid Muhammad bin Muhammad Ibnu Rusyd, Bidayatul Mujtahid Analisa Fiqih Para Mujtahid, (Jakarta: PUSTAKA AMANI, 1989. 
Andhika Yudho Prasetyo, (Penyalahgunaan Obat Sebagai Alat Penggugur Kandungan Dalam Perspektif Hukum Pidana Indonesia dan Hukum Pidana Islam, 2015), (Fakultas Syariah dan Hukum, UIN Syarifhidayatullah Jakarta.

Andi Hamzah, KUHP DAN KUHAP,( Jakarta ; Rineka Cipta, 2010.

Budi Utomo dkk, Angka Aborsi dan Aspek Psiko-sosial di Indonesia: Studi di 10 kota

CB. Kusmaryanto, Kontroversi Aborsi, (Jakarta: PT. Grasindo, Anggota IKAPI, 2002), Cetakan pertama.

Dewi Indraswati, Fenomena Kawin Muda dan Aborsi: Gambaran Kasus dalam Hasyim, S, Menakar Harga Perempuan,(Jakarta: Sinar Grafika, 2001.

Elga Sarapung, Masrucah, M. Imam Aziz, Agama dan Kesehatan Reproduksi", (Jakarta: Pustaka Sinar Harapan, 1999), Cetakan pertama.

Eny Kusmiran, dan Kesehatan Reproduksi Remaja Wanita,(Jakarta : Penerbit Salemba Medika, 2011.

Hafiz Dasuki, Ensiklopedi Hukum Islam, (Jakarta: PT Ichtiar Baru Van Hoeve, 1997),

Hasdianah Hasan Rohan dan Sandu Siyoto, Buku Ajar Kesehatan Reproduksi, (Yogyakarta: Nuha Medika, 2013), cetakan pertama.

Huzaemah Tahido Yanggo, Fikih Perempuan Kontemporer, (Jakarta: Ghalia Indonesia, 2010.

Huzaimah Tahido Yanggo, Masail Fighiyyah Kajian Hukum Islam Kontemporer, (Bandung: Angkasa Bandung, 2005), cetakan pertama.

Ibrahim Amini, Anakmu Amanatnya Buah Sebagai Sekolah Utama, (Jakarta: Al-Huda, 2006), Cetakan Pertama.

Ika Wahyuni Novianti (Dispensasi Aborsi Dalam PP No 61/2014 Menurut Tokoh Aisyiyah Muhammadiyah dan Tokoh Muslimat NU, 2014), Fakultas Syari'ah dan Hukum UIN Syarifhidayatullah Jakarta.

Imam Muslim, Shahih Muslim. (Beirut: Dar El Fiker, 1993. Hadis 2643, jilid 2, h. 412). Lihat juga hadis 2645.

Kementrian Agama RI Badan Litbang dan Diklat Lajnah Pentashihan Mushaf Al-Qur'an, Seksualitas Dalam Perspektif Al-Qur'an dan Sains Tafsir Ilmi, (Jakarta : Perpustakaan Nasional RI Katalog Dalam Terbitan, 2012), cetakan pertama.

Layyin Mahfiana dkk, Remaja dan Kesehatan Reproduksi, (Yogyakarta : STAIN Ponorogo Press, 2009), cetakan pertama.

M Nurul Irfan, (Gratifikasi dan Kriminalitas Seksual Dalam Hukum Pidana Islam), (Jakarta: Amzah.2014. 
M. Ali Hasan, Masail Fiqhiyyah Al- Haditsah Pada Masalah-Masalah Kontemporer Hukum Islam, (Jakarta: PT Raja Grafindo Persada, 2000 ), Cet 4.

M. Ikhsanudin, (Jika Ulama Mengkaji Aborsi Antara Muhammmadiyah dan $N U)$, ( Yogyakarta: Universitas Gajah Mada, 2005),cetakan pertama.

M. Nu"aim Yasin, Fiqih Kedokteran, (Jakarta : Pustaka Al -Kautsar, 2001), Cet. Ke-III.

Maria Ulfa Anshor, dkk, (Aborsi Dalam Perspektif Figh Kontemporer), (Jakarta : Balai Penerbit Fakultas Kedokteran Indonesia, 2002.

Maria Ulfa Anshor, Fikih Aborsi (Wacana Penguatan Hak Reproduksi Perempuan). (Jakarta: Buku Kompas, 2006), Cetakan pertama.

Masjfuk Zuhdi, Masail Fighiyyah Kapita Selekta Hukum Islam, (Jakarta: PT. Toko Gunung Agung, 1997.

Muhammad Abduh Malik, (Perilaku Zina Pandangan Hukum Islam dan KUHP), (Jakarta: PT. Bulan Bintang, 2003), cetakan pertama.

Muhammad Sidqi Bin Ahmad Al-Burniu, Al-Waziz Fi Idah Qawaidul Fighi Al-Quliah, (Riat: Muasasah Ar-Risalah.

Muhammad Sidqi Bin Ahmad Al-Burniu, Al-Waziz Fi Idah Qawaidul Fighi Al-Quliah, (Riat: Muasasah Ar-Risalah.

Mustopa Dib Al-Baqa, At-Tadhib Fii Adhilati Matan Al-Qoyah Wal Taqrif, (Surabaya: Toko Kitab Al-Hidayah), TTH.

Neng Djubaedah, (Perzinaan Dalam Peraturan Perundang-undangan di Indonesia ditinjau dari Hukum Islam), (Jakarta: Kencana Prenada Media Group, 2010), Cetakan ke-1.

Nunik widiyantoro, Konstruk Seksualitas dan Hak-hak Rreproduksi Perempuan, (Yogyakarta: Yayasan Kesehatan, 2001.

Nunik Widyantoro,( Pengakhiran Kehamilan Tak Diinginkan yang Aman Berbasis Konseling), (Jakarta: Yayasan Kesehatan Perempuan, 2003.

Sahal Mahfudh, Figh Sosial; Upaya Pengembangan Mazhab Qouli dan Mazhab Manhaji, (Jakarta: UIN, 2003.

Soekidjo Notoatmodjo, Etika dan Hukum Kesehatan, (Jakarta : Rineka Cipta, 2010.

Sri Siswati, Etika dan Hukum Kesehatan dalam Perspektif Undang-Undang Kesehatan, (Jakarta: PT Raja Grafindo Persada, 2013), cetakan pertama.

Supriyadi Widodo Eddyono, dkk, ( Kejahatan Perkosaan dalam RUU KUHP ), Jakarta: Elsam Dan Tifa, 2007,cetakan pertama.

Tim Penyusunan Kamus Pusat Pengembangan dan Pembinaan Bahasa, Kamus Besar Bahasa Indonesia, Jakarta: PT. Gramedia Pustaka Utama, 1990. 
Tim Salsilah, Ensiklopedia Hukum Pidana Islam II, At-Tasyri' al-Jinaiy alIslamiy Muqaranan bil Qanunil Wad'iy, Bab Zina) (Jakarta: PT. Kharisma Ilmu, diterjemahkan oleh Tim Salsilah, 2006.

Wahbah Zuhaili, al-Fighu al-Islami wa adillatuhu, Damaskus, DaaralFikr, 1984), Juz V.

Wiknjosastro, dkk, Aborsi Dalam Perspektif Figh Kontemporer, Jakarta: Buku Kompas, 2006.

Wila Chandrawila Supriadi, Hukum Kedokteran, Bandung : Mandar Maju, 2001, cetakan pertama.

Yudho Prasetyo, Penyalahgunaan Obat Sebagai Alat Penggugur Kandungan Dalam Perspektif Hukum Pidana Indonesia dan Hukum Pidana Islam, Jakarta: UIN, 2015.

Yusuf Qordhowi dkk, Ensiklopedi Muslimah Modern, Jakarta: Pustaka Iman, 2009. 